\title{
Harmful Algal Blooms: Physiology, Behavior, Population Dynamics and Global Impacts- A Review
}

\author{
Al-Ghelani, H.M.*, AlKindi, A.Y.A**, Amer, S.* and Al-Akhzami, Y.K*. \\ *Ministry of Agriculture and Fisheries, P.O.Box 467, Al Khuwair 113, \\ Muscat, Sultanate of Oman, ${ }^{\star \star}$ Department of Biology, Sultan Qaboos \\ University, P.O.Box 36, Alkhod 123, Muscat, Sultanate of Oman, \\ **Email: aakindy@squ.edu.om.
}

إزنهار اللحالب الضارة: الجولب الفيزبولوجية والسلوكية لها ونموها وتنأثيرها العالمي

حمد بن محمد الغيلان ، عبدالعزبز الكني سشهلة عامر ويوس بن خلفلن الخزمي

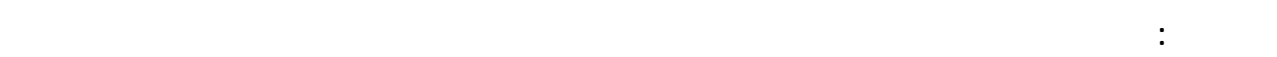

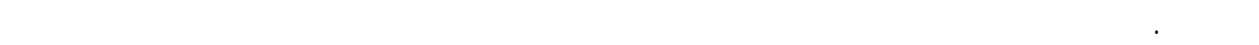

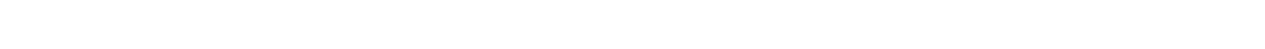

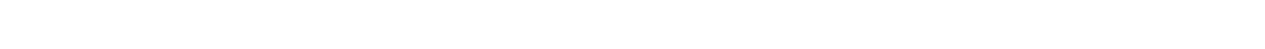

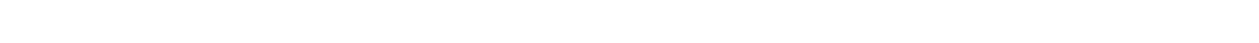

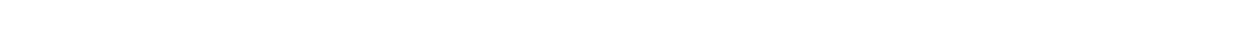

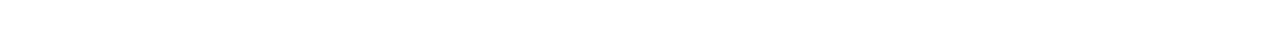

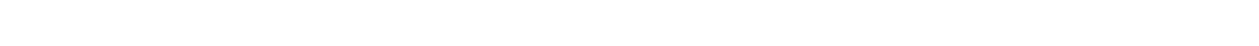

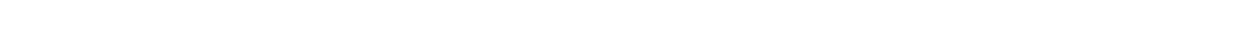

الكائنات ولسببل تأثيرها.

ABSTRACT: Harmful, toxic algae are now considered as one of the important players in the newly emerging environmental risk factors. The apparent global increase in harmful algal blooms (HABs) is becoming a serious problem in both aquaculture and fisheries populations. Not only has the magnitude and intensity of public health and economic impacts of these blooms increased in recent years, but the number of geographic locations experiencing toxic algal blooms has also increased dramatically. There are two primary factors causing HABs outbreaks. The natural processes such as upwelling and relaxation, and the anthropogenic loading resulting in eutrophication. However, the influence of global climate changes on algal bloom phenomenon cannot be ignored. The problem warrants development of effective strategies for the management and mitigation of HABs. Progress made in the routine coastal monitoring programs, development of methods for detection of algal species and toxins and coastal modeling activities for predicting HABs reflect the international concerns regarding the impacts of 
HABs. Innovative techniques using molecular probes will hopefully result in development of rapid, reliable screening methods for phycotoxins and the causative organisms.

KEYWORDS: Harmful algal blooms, phycotoxins, eutrophication, toxigenic algae, biotoxin, upwelling.

\section{Introduction}

$\mathbf{M}$

arine phytoplankton develops over various scales of space and time (Harris, 1986), one of which includes the massive, relatively sudden and local or geographically restricted outbursts of one or sometimes a few species. Such phenomena are given one of a few names: 'red tides', 'brown water', 'discoloured waters', 'colored waters'. All these terms imply that algal proliferation is so intense as to modify the appearance of the sea surface as perceived by human eye. Red tides refer to the bio optical phenomena and rely implicitly on a threshold of a plant biomass or light extinction; several attempts have been made to estimate this threshold in terms of cell numbers, total cell volume and carbon content (Kim et al. 1993) or chlorophyll content (Allen, 1946; Saunders and Glenn, 1969; Tett, 1987). On the other hand, blooms (originally, the regular spring growth in temperate waters) are ecophysiological rather than bio-optical in meaning; being typically harmless. Phyoplankton or single celled marine plants are organisms at the base of the food chain that are the food for many higher organisms. These microscopic planktonic algae are critical food for filter-feeding bivalve fish as well as the larvae of commercially important crustaceans and finfish. In most cases, the proliferation of planktonic algae, so-called ('algal blooms', up to millions of cells per litre) is therefore beneficial for aquaculture and wild fisheries operations (Hallegraeff, 1993).

In some situations algal blooms can have a negative effect, causing severe economic losses to aquaculture, fisheries and tourism operations and having major environmental and human health impacts. Red tides may be harmless or harmful to the surrounding fauna, man included, and they can be dramatically harmful when the causative organism produces a toxin (Sournia, 1995). However, toxin-producing microalgae may be deleterious even when present in low or moderate concentrations. Therefore:

(i) red tides are not all toxic

(ii) toxic phytoplankters do not all produce red tides.

\section{Definition}

Generally, approximately 1 million cells per liter of seawater equals a bloom which may also produce biotoxins. These events are termed harmful algal blooms or HABs. Attendees at the 1984 ICES Exceptional Plankton Blooms Meeting concluded that exceptional blooms should be defined in terms of the deviation from the normal cycle of phytoplankton biomass (Parker, 1987). HABs were defined as phytoplankton blooms where the effects are noticeable and or harmful. The term 'harmful' algal blooms (HABs) referred to as 'red tides", has been applied to a class of blooms increasingly thought to have unique properties (Smayda, 1997). This emergent bloom phenomenon is rapidly expanding in global coastal waters (Anderson, 1989; Smayda, 1990; Hallegraeff, 1993).

Richardson (1989) defined a bloom as an outburst resulting in 'high biomass', stating also that 'a red tide is an exceptional bloom'. According to Richardson (1997), phytoplankton (also called "microalgal or algal") bloom is the rapid growth of one or more species leading to an increase in biomass of the species. Exceptional phytoplankton blooms have also been defined as "those which are noticeable, particularly to the general public, directly or indirectly through their effects such as visible discoloration of water, foam production, fish or invertebrate mortality or toxicity to human (ICES, 
1984). Reid et al. (1987) applied the term "exceptional” to blooms of microalgae, accompanied by 'deleterious side-effects.' Cellular abundance levels have also been used to define red tide blooms. Kim et al. (1993), classify blooms as 'red tides' (in Korean waters) when abundance of the causative species $(>30 \mu \mathrm{m})$ exceeds 1000 cells $\mathrm{ml}^{-1}$. This criterion results in about 200 diatom species being classified as red tide species, which represents about two thirds (65\%) of the total number of species classified as such (Sournia, 1995).

Blooms, as a phenomenon collectively have properties other than biomass, numerical population density, and the potential of the bloom species to inflict harm. Harmful effects may therefore accompany very high $\left(\sim 10^{8}\right.$ cells $\left.\mathrm{l}^{-1}\right)$ or very low $\left(<10^{3}\right.$ cellsl $\left.^{-1}\right)$ biomass. Furthermore, bloom events may occur at very low $\left(<10^{3}\right.$ cells $\left.\mathrm{l}^{-1}\right)$ or very high $\left(\sim 10^{8}\right.$ cells $\left.\mathrm{l}^{-1}\right)$ cellular abundance, and may be due to very small or very large species' size. In both cases same species may be simultaneously inimical to several trophic components or have multiple effects and for different reasons. The presence of a toxic species does not necessarily lead to a deleterious impact. Such effects require a threshold population density level, above which it becomes inimical. The population level at which this occurs need not be accompanied by seawater discolouration, contrary to anecdotal perceptions of red tides.

\section{Harmful Algal Blooms}

\subsection{History}

It is often cited that the first written record (1000 B.C.) of a harmful algal bloom appears in the Bible: ' ... all the waters that were in the river were turned to blood. And the fish that was in the river died; and the river stank, and the Egyptians could not drink of the water of the river' (Exodus: 20-21, Moore, 1977; Hallegraeff, 1995). However, there is fossil evidence that harmful algal blooms were occurring long before this. Noe-Nygaard et al. (1987) have suggested, on the basis of the distribution of dinoflagellate cysts and bivalve shells in fossil sediments taken from island of Bornholm in the Baltic Sea, that toxic dinoflagellates caused mass mortalities of bivalves on several occasions dating back to about 130 million years ago. Dale et al. (1993) have also studied the distribution of fossil dinoflagellate cysts and presented evidence suggesting bloom formation by the toxic dinoflagellate Gymnodium catenatum in the Kattegat-Skagerrak long before anthropogenic activities could have influenced these waters. The species first appeared in the region about 6000 years ago and achieved a minor peak in production about 4500 years ago. After that it occurred in relatively low numbers until about 2000 years ago. During the next 1500 years periodic blooms of the species took place. In the sediment records for the last 300 years these workers found no evidence of this dinoflagellate. The fossil records emphasize two important points with respect to exceptional algal blooms (Richardson, 1997):

i. The occurrence of such blooms is not a recent phenomenon i.e., anthropogenic perturbation of the environment is not a necessary prerequisite for all exceptional blooms

ii. Phytoplankton species are not necessarily permanent residents of a given body of water.

\subsection{Causative Organisms}

The numbers of species within each phytoplankton class implicated in the formation of harmful bloom or red tides have been estimated by Sournia (1995). According to him the dinoflagellates (Dinophyceae) comprise the class which is numerically the largest and it is also within this class that one finds the greatest numbers of both exceptional / harmful bloom forming and toxic species. Estimates show that 5.5-6.7\% of the known phytoplankton species in the world's oceans, i.e. about 200 species, have been identified as causing exceptional or harmful blooms (Sournia, 1995; Skulberg et al. 1993; Steidinger, 1996; Hasle and Syvertsen, 1996; Throndsen, 1993; Taylor et al. 1995; Landsberg, 2002). About half of these species are dinoflagellates, while diatoms are probably the second most important algal class in terms of causing exceptional or harmful blooms (Sournia, 1995). 
However, toxic species are about four times less numerous (60-78) than red tide species, but still represent 1.8-1.9\% of the world flora (Sournia, 1995), with numbers increasing by not more than 2030 species (Bomber, 1991; Shimizu, 1987; Elbrachter, 1990; Hawser et al. 1991). Approximately 75\% of the species that have been identified as being toxic belong to the Dinophyceae and most of these belong to the order Peridiniale, Gymnodiniales and Dinophysales. Four genera (Alexandrium, Dinophysis, Gymnodium and Prorocentrum) dominate in terms of causing toxic blooms (White, 1979; Skulberg et al. 1993; Steidinger, 1996; Steidinger et al. 1996; Taylor et al. 1995).

\subsection{Impacts of Harmful Algal Blooms}

There is an increase in phytoplankton events in number, geographical extent, frequency, number of species, intensity and damages (Boalch, 1983; Anderson, 1989; Smayda, 1990; Sournia et al. 1991; Hallegraeff, 1993).

Three modes of negative impact have resulted in characterrising certain species as 'harmful'. They are described as : 'toxic' (Anderson et al. 1985), 'noxious' (Horner et al. 1990) or 'nuisance' (Hallegraeff, 1993). The three major impacts of the harmful blooms are:

1. A number of toxins produced by phytoplankton that affect humans also affect fish (White, 1977; Gosselin et al. 1989; Riley et al. 1989; Robineau et al. 1991; Noga, 1998). In addition, however some bloom forming phytoplankton species that have not been shown to be toxic to human produce toxins that affect fish or other marine organisms (Moshiri et al. 1978; Granmo et al. 1988; Heing and Campbell, 1992; Eilertsen and Raa, 1994). Phytoplankton species which cause fish-poisoning (Ciguatera) and shell-fish vectored poisoning of humans are clearly harmful (Hallegraeff, 1993). Public health concerns over-bloom related, shellfish borne diseases affecting seafood safety are an emergent global concern.

2. Species whose blooms induce die-offs of farmed fish and cultivated shellfish leading to aquacultural financial losses are also harmful. Gelatinous secretion during an unusual bloom of the diatom Coscinodiscus wailessi in the North Sea was so great that the weight of the slime tore fishing nets and impaired the fishery (Boalch and Harbour, 1977). Deflections of migratory routes (Savage, 1930), emigrations (Lenanton et al. 1985) and other avoidance reactions (Potts and Edwards, 1987) of commercially important fish during harmful blooms also occur.

3. The third major category of impact-field and experimental evidence reveals at least eight different modes and mechanisms by which harmful species cause mortality or physiologically impair target victims (Table 1). These fall in two general types:

i. Non-chemical effects: Effects, which lead to starvation or cause harmful mechanical and physical damage.

ii. Chemical effects: Attributable to physical-chemical reaction, phycotoxins or other metabolites.

Starvation impaired growth and fecundity resulting from nutritional and prey size mismatches are well-known experimental results, (Smayda, 1997). Excess prey density $\left(>250 \times 10^{6} \mathrm{l}^{-1}\right)$ of the brown tide species, Aureococcus anophagefferens, led to a spawning failure and mortality of the mussel, Mytilus edulis (Tracey, 1988; Nuzzi and Waters, 1989; Smayda and Villareal, 1989). This organism has also been shown to reduce or stop filter feeding in some shellfish (Tracey, 1988; Gallager et al. 1989; Gainey and Shumway, 1991).

Mechanical damage leading to death of larval fish can result from collisions ("bumping”) with dinoflagellates at high bloom population densities (Ho and Zubkoff, 1979). Lethal piercing of gill filaments of penned and feral population of fish and crustaceans by the setae of Chaetoceros diatoms also can occur (Horner et al. 1997; Rensel, 1993; Yang and Albright, 1992; Tester and Mahoney, 1995). Respiratory failure, haemorrhaging, or bacterial infection resulting from such particle irritation can cause mortality. Extra cellular polymer secretions of harmful species can induce mortality in three physical ways; as a viscosity barrier (Partensky et al. 1989; Potts and Edwards, 1987); by forming a gelatinous barrier (Taylor et al. 1985) and through mucoid layer reduction (Endo et al. 
1985). Gill clogging, elevated shear stress, which tears gill filaments and osmoregulatory failure can lead to death (Endo et al. 1985, 1992).

Table 1. Mortality modes and impact mechanisms of harmful species and their blooms (Source : Smayda, 1997).

\begin{tabular}{|l|l|}
\hline \multicolumn{1}{|c|}{ Modes } & \multicolumn{1}{c|}{ Impact } \\
\hline Starvation & $\begin{array}{l}\text { NutritionL Mismatch } \\
\text { Size mismatch } \\
\text { Excess prey density }\end{array}$ \\
\hline Mechanical & $\begin{array}{l}\text { "Bumping" } \\
\text { Particle irritation (chaetoceros spp.) }\end{array}$ \\
\hline Physical & $\begin{array}{l}\text { Viscosity barrier (Gyrodinum areolum) } \\
\text { Gelatinous barrier (Ceratulina pelagica) } \\
\text { Mucoid layer reduction (Chattonella marina) }\end{array}$ \\
\hline Anoxia & Ceratium blooms \\
\hline NH ${ }_{4}$ toxicity & Noctiluca blooms \\
\hline Phycotoxins & $\begin{array}{l}\text { Direct vs. vectored toxicity } \\
\text { Saxitoxin } \\
\text { Brevetoxins } \\
\text { Hemolysins } \\
\text { Cytotoxins }\end{array}$ \\
\hline Allelopathic & Pfiesteria piscicida \\
\hline Ambush predation & Aureococcus anophaghagefferens \\
\hline Unresolved & \\
\hline
\end{tabular}

Among the chemically harmful mechanisms die off due to anoxia or hypoxia following blooms of large, relatively ungrazed species such as Ceratium are well-known (Graneli et al. 1989; Mahoney and Steimle, 1979). Noctiluca produced a remarkably simple ichthyotoxin: $\mathrm{NH}_{4}$ (Okaichi and Nishio, 1976). In contrast phycotoxins have much more elaborate effects. Mortality can occur through direct ingestion of endotoxin of the harmful species (Carmichael, 1996), upon exposure to secreted toxins (exotoxins; Hansen et al. 2000) or from toxin vectoring through the food web, accompanied by conformational changes in the toxic principles and their potencies (Shimizu, 1987; Shimizu et al. 1989; Yasumoto and Murata, 1993). The impact may be on a directly targeted predator or may lead to indiscriminate die-offs and physiological impairment during food web vectoring (Landsberg, 2002). Specific toxins are water or lipid soluble and have cytolytic, haemolytic (Hansen et al. 2000) or neurotoxic activity (Perovic et al. 2000; Daugbjerg et al. 2000). Allelopathic substances are distinguished from phycotoxins in being secondary metabolites (Subba Rao et al. 1995; Wright and Cembella, 1998; Naviner et al. 1999) and both can co-occur within a given harmful species. Allelopathic substances tend to be directly targeted and may physiologically impair, stun, repel, induce avoidance reactions or kill grazers (Plumley, 1997; Wyatt and Jenkinson, 1997, Fistarol et al. 2004). Examples of these diverse modes of impact have been demonstrated by Smayda (1992). A relatively newly discovered, remarkable ambush predatory behavior of the harmful dinoflagellate Pfiesteria piscicida has been presented by Burkholder and Glasgow (1995, 1997), Burkholder et al. (1992, 1999, 2001), and Berry et al. (2002) and Vogelbein et al. (2002). 


\subsection{Types of Harmful Algal Blooms}

Harmful and toxic species are a small subset of the total phytoplankton flora and little is known about the inter-annual variability with respect to the relative frequency of occurrence of different phytoplankton species. The three different types of harmful HABs are:

1. In some cases, a non-toxic bloom forming alga becomes so densely concentrated that it can generate anoxic conditions resulting in indiscriminate kills of both fish and invertebrates due to oxygen depletion. For example, Dinoflagellates, Gonyaulax polygramma (Lam, 1988) Noctiluca scintillans. (Okaichi and Nishio, 1976; Chen and Qi, 1991; Ho and Hodgkins, 1992; Xie, et al. 1993; Hong and Huang, 1989; Qi et al. 1992, 1993, 1995; Qi and Li, 1994) and Cynobacterium: Trichodesmium erythraeum (Endean et al. 1993).

2. Species that produce potent toxins that can find their way through the food chain to humans (Table 2), cause a variety of gastrointestinal and neurological illnesses such as Paralytic Shellfish Poisoning (PSP; Lush and Hallegraeff, 1996). For example, Dinoflagellates, Alexandrium acatanella (Cembella et al. 1987), Alexandrium minutum (Chen and Chou, 2001) Alexandrium fundyense (Anderson et al. 1990). Most humans who experience paralytic shellfish poisoning have consumed toxic bivalves (Shumway, 1990) and toxic gastropods and crustaceans (Shumway, 1995). Whales and porpoises can also become victims when they receive toxins through the food chain via contaminated zooplankton or fish (Geraci et al. 1989).

3. The third type of harmful algal bloom has been apparent only as a result of the increased interest in intensive aquaculture systems for finfish. Some algal species can seriously damage fish gills, either mechanically (Berry et al. 2002) or through production of haemolytic substances (Hansen et al. 2000).

Table 2. Potency of some algal blooms (Source: Wyatt, 1998)

\begin{tabular}{|l|l|c|}
\hline \multicolumn{1}{|c|}{ Toxin } & \multicolumn{1}{c|}{ Source } & Toxicity \\
\hline Cyanide & & 1 \\
\hline Muscarin & Amanita muscaria, fungus & 9 \\
\hline Okadaic acid & Algae, dinflagellates (e.g. Dinophysis spp.) & 50 \\
\hline Domoic acid & Algae, diatoms (Pseudo-nitzschia spp.) & 80 \\
\hline Prymnesium & Algae, haptophytes (e.g. Prymnesium parvum) & 350 \\
\hline Cobra toxin & Cobra snake & 500 \\
\hline Saxitoxin & $\begin{array}{l}\text { Algae, dinoflagellates } \\
\text { (e.g. Alexandrium spp., Pyrodinum bahamense) }\end{array}$ & 1100 \\
\hline Ciguatoxin & Algae, dinoflagellates (Gambierdiscus toxicus) & 22000 \\
\hline Tetanus toxin & Bacterium (Clostridium tetani) & 100000000 \\
\hline
\end{tabular}

\section{Harmful Algal Events}

Upwards of ten thousand named species of plank-toxic algae are found in the upper layers of the oceans and continental waters. Excluding those which respond to eutrophication and associated processes and which can give rise to biomass problems, less than a hundred of these have so far been recorded as harmful (Wyatt, 1998).

Three distinct periods of harmful algal events can be distinguished:

1. Events due to accumulation of biomass of microplanktonic cells (larger than $20 \mu \mathrm{m}$ in diameter), often associated with natural or anthropogenic eutrophication, which are normally composed of different species. In these cases, unrestrained growth of algae can lead to very high cell concentration. If these populations are neither grazed nor dispersed by winds and tides, their death and decay can lead to deoxygenation in the sediments where they settle 
(Okaichi and Nishio, 1976; Onoue, 1990; Olsgard, 1993) in the lower water column and consequent mortalities of other components of the ecosystem are affected. Anoxia and or bacterial infection in combination with the damaged gill tissue leads to mortality of the fish (Jones and Rhodes, 1994; Tester and Mahoney, 1995). Hypoxia or anoxia resulting from the respiration or decay of dense blooms of phytoplankton can also, on its own, lead to fish or shellfish kills- especially of caged fish that are unable to swim from the affected area (Steimle and Sindermann1978; Taylor et al. 1985).

Events of this kind are common, often annual, in many parts of the world, especially in shallow, semi-enclosed and poorly furnished estuaries and lagoons but less frequently in open sea areas such as the Northern Adriatic Sea or the New York Bight, when the balance between nutrient supplies and flushing rates tips in favour of such events (Wyatt, 1998)

2. There are blooms of single microplanktonic species with particular morphological, physiological or biochemical features which interact in negative ways with other organisms in the environment, either directly or through the food web. For example, (i) some diatoms in the genus Chaetoceros cause much damage to the gills of caged fish (Ianora et al. 1995); (ii) the diatom Coscinodiscus wailesii, a water blooming species competes for nutrients with the red microalgae Porphyra which is farmed in Japan and other countries; and (iii) the dinoflagellate Gyrodinium aureolum, (frequently referred to as Gymnodium), (Mahoney et al. 1990) can cause potentially lethal respiratory distress in fish and other organisms brought about by secretion of large quantities of mucilaginous materials (Wyatt, 1998). But many harmful species in this group are poisonous and produce compounds which can cause paralytic, neurotoxic, diarrhetic and other effects when transmitted through the food web to vertebrates including man.

3. Events due to accumulation of biomass of ultraplanktonic cells (between 0.2 and $20 \mu \mathrm{m}$ in diameter). Events of this kind are less common, but can be very persistent as in the case of the Texas 'brown tide' which has persisted in Laguna Madre for more than seven years (Wyatt, 1998).

\section{Rise of Algal Blooms}

The issue of a global increase in harmful algal blooms has been raised previously in Conference proceedings (Anderson 1989; Hallegraeff et al. 1990; Smayda, 1990), while the biology of toxic dinoflagellates has been reviewed by Steidinger (1993) while the facts of algal blooms on aquaculture have been summarized by Shumway (1990). Four possible explanations for the apparent rise of algal blooms are:

- Increased scientific awareness of toxic species

- Increased utilization of coastal waters for aquaculture

- Stimulation of plankton blooms by cultural eutrophication

- Unusual climatologic conditions and transport of dinoflagellate resting cysts either in ships ballast water or associated with movements of shellfish stocks from one area to another.

\subsection{Increased Scientific Awareness of Toxic Species}

Reports of harmful algal blooms associated human illnesses or damage to aquaculture operations are receiving increased attention in media and scientific literature. Concerns about aquatic biotoxin, particularly from micro-organisms, stems from an increased dependency on aquatic environments for food and potable water as well as on their potential source for drugs and other chemicals and modern aspects of genetic engineering (Colwell. 1983). These potent materials from natural sources are of more than just academic interest, since they may cause massive animal mortalities, as well as legal, 
recreational and human health problems (Hashimoto, 1979: Carmichael, 1981, 1986; White, 1982; Baden, 1983; Ragelis, 1984; Van Dolah, 2000). Until 1988, the type of species A.minutum was known to be in Egypt only (Halim, 1960). But it has recently been reported in Australia, France, Spain, Portugal, Italy, Turkey and the east coast of North America (Hallegraeff et al. 1991).

\subsubsection{Toxic Algal Blooms}

Relatively few species among the primary producers produce potent materials which may affect organisms at other trophic levels in the food chain. In general a biotoxin is a harmful substance synthesized by one species and adversely affects other species when present in extremely small quantities. Toxins are characterized by their potency ( $\mu$ g toxin $\mathrm{kg}^{-1}$ body mass), their specificity of action (e.g. ion channels in membranes) and, in some cases, their reversibility. The latter characteristic has attracted the attention of physiologists and pharmacologists who study basic phenomena at the membrane level (Hashimoto, 1979; Adelman et al. 1982; Kao and Walker, 1982; Baden, 1983; Sasner et al. 1984).

In general, the major producers of toxins are the dinoflagellate and diatom groups in the marine environment and cyanobacteria in fresh and brackish waters. Dinoflagellates constitute the most prevalent of the toxic marine algae and their effects are widespread and disastrous. The effects may be generally classified as paralytic shellfish poisoning, diarrhetic shellfish poisoning, ciguatera poisoning and ichthyotoxicity.

\subsubsection{Diarrhetic Shellfish Poisoning}

The phenomenon of diarrhetic shellfish poisoning (DSP) was first documented in 1976 from Japan where it caused major problems for the Scallop Fishery (Yasumoto et al. 1978). The first dinoflagellate to be indicated was Dinophysis fortii (in Japan). It was soon followed by the $D$. acuminata (in Europe), D. nutra, D. rotunda and the benthic dinoflagellate Prorocentrum lima (Aune and Yndestad, 1993) and Prorocentrum excavata (Rausch de Traubenberg and Morlaix, 1995). The DSP toxins include Okadaic acid and polyether toxins, Dinophysistoxins (DTX1-4) (Aune and Yndestad, 1993), pectenotoxins and yessotoxins (Yasumoto, 1985; WHO, 1984). A number of dinoflagellate species (Hallegraeff, 1993), especially from the genus Dinophysis, have been identified as producing these toxins. The detection of DSP toxins in the heterotrophic dinoflagellates Protoperidinium occanicum and P. pellucidum (Lee et al. 1991) may reflect their feeding on Dinophysis.

The symptoms of DSP include stomach pain, nausea, vomiting and diarrhoea (WHO, 1984). No fatalities directly associated with DSP have ever been recorded (Richardson, 1997). However, some of the toxins associated with DSP may promote the development of stomach tumours (Suganuma et al. 1988).

\subsubsection{Amnesic Shellfish Poisoning}

Amnesic shellfish poisoning (ASP) gets its name from the fact that one of the symptoms of the poisoning is loss of memory. It was first recognized in 1987 on Prince Edward Island on Canadian East Coast when a serious incident occurred which caused three human fatalities and 105 cases of acute poisoning following the consumption of blue mussels Mytilus edulis (Bates et al. 1989). Clinical symptoms of ASP are nausea, vomiting, abdominal cramps, diarrhea, memory loss, decreased level of consciousness, seizures, confusion and disorientation (Wright et al. 1989; Perl et al. 1990; Todd, 1990; Nijjar and Nijjar, 2000). The cause of this poisoning was traced to a bloom dominated by the pinnate diatom, Pseudo-nitzschia multiseries (formerly Pseudonitzschia pungens f. multiseries) which produces the neurotoxin domoic acid (DA) (Subba Rao et al. 1998; Bates et al. 1989, 1995). Lundholm et al. (1994) have shown that the diatom Pseudo-nitzschia seriata also produces domoic acid at levels similar to those observed with Pseudo-nitzschia multiseries. This diatom is common in 


\section{HARMFUL ALGAL BLOOMS}

colder waters of the Northern Hemisphere. There is also an indication in the literature that several other common diatom species may produce domoic acid e.g., Fragilaria spp (Pauley et al. 1993), Amphora Coffeaeformis (Maranda et al. 1990), Nitzchia pungens .f. multiseries, N.pseudo delicatissima and N. pseudo seriata (Pseudonitzchia australis Frenguelli) (Subba Rao et al. 1998, Martin et al. 1990, Work et al. 1992; 1993). The production of DA has been identified in nine species of Pseudonitzschia and one species of Nitzschia (Bates et al. 1989; Bates, 2000). These diatoms produce toxins only after the onset of the stationary growth phase which is induced by either phosphate or silicate deficiency (Bates et al. 1991).

\subsubsection{Paralytic Shellfish Poisoning}

Existence of paralytic shellfish poisoning (PSP) has been recognized for many centuries. This form of shellfish poisoning induces muscular paralysis and in severe cases can lead to death through paralysis of respiratory muscles. PSP is caused by toxins often referred to collectively as "PSP toxins". The structure of the most potent component of the PSP toxin is called saxitoxin and referred to as STX. Its structure was determined about 30 years ago. It is now known that PSP is caused not by just one toxin but a group of toxins, based on the backbone structure of the saxitoxin molecule (Cembella et al. 1987; Hall et al. 1990). PSP is caused by one or more of about 18 different toxins which, include saxitoxins, neosaxitoxins and gonyautoxins (Fremy, 1991). With the exception of the African and parts of the South American Coasts, PSP is a worldwide problem (Hallegraeff, 1993), although some evidence (Baddyr, 1992) suggests that PSP incidents have occurred along the Morrocan Coast during the 1980s and 1990s.

Paralytic shellfish toxins are produced by dinoflagellates - approximately 11 Alexandrium species, Gymnodium catenatum, and Pyrodinium bahamense var. Compressum- and by cyanobacteria Anabena circinalis, Aphanizomenon flos-aquae, Cylindrospermopsis raciborskii, Lyngbya wollei and Planktothrix sp. (Scholin, 1998; Balech, 1995). Anderson et al. (1990) examined different PSP producing dinoflagellates (Alexandrium fundyense and A. tamarense) and identified differences in toxin production that were directly related to changes in growth rate associated with the various stages of the life cycle.

Shellfish are the usual vectors of PSP to human consumers. However, crustaceans can also accumulate PSP toxins (Desbiens and Cembella, 1995). PSP toxins have been found in the zooplankton and guts of dead and diseased fish in the vicinity of blooms (White, 1977). Some PSP toxins have also been found in the muscle of the affected fish and there is at least circumstantial evidence that PSP toxins may be implicated in mortalities of marine animals (Hofman, 1989; Anderson and White, 1992). A number of studies have indicated reduced grazing rates by copepods on PSP containing phytoplankton (Ives 1985, 1987; Huntley et al. 1986; Turriff et al. 1995).

\subsubsection{Neurotoxic Shellfish Poisoning}

Blooms of the dinoflagellate Ptychodiscus breve (formerly Gymnodium breve) have been associated with human poisoning which is characterized by airborne bronchial irritation and neurological symptoms but no paralysis (Baden, 1989; Schulman et al. 1990). Brevetoxins, which have been isolated in pure form (Chou et al. 1985; Baden and Mende, 1982), have high molecular weight, and are lipid soluble, non-nitrogen containing complex polyethers.

\subsubsection{Ciguatera}

Ciguatera poisoning has been known for centuries in subtropical and tropical areas (Swift and Swift, 1993; Lewis et al. 2000). During the period, 1960-1984, over 24,000 cases were reported in French Polynesia alone (Hallegraeff, 1993). Ciguatera is caused by benthic dinoflagellates such as Gambierdiscus toxicus, (Faust, 1995; Chinain et al. 1999); Ostreopsis siamensis, Coolia monotis, Prorocentrum lima and related species (Anderson and Lobel, 1987; Hallegraeff, 1993, Hu et al. 
1996). These toxins are transported through the food chain and usually reach humans through the consumption of finfish (Lewis and Holmes, 1993).

There are chemical similarities between ciguatoxin and brevetoxins and the toxic effects of both these types of toxins are apparently caused by the changes in sodium ion influx in the affected organisms (Baden, 1989, 1995; Trainer et al. 1990). Many of the symptoms associated with ciguatera poisoning also resemble NSP and in severe cases, death can result from circulatory collapse or respiratory failure due to NSP (WHO, 1984). Ciguatoxins have also been implicated in marine mammal kills (Hofman, 1989).

\subsubsection{Cyanobacterial Toxins}

Toxic cyanobacteria (blue-green algae) blooms are most often associated with fresh waters. However, it has been recently shown that blooms of the cyanobacterium Trichodesmium thiebautii occurring in the open Ocean of the US Virgin Islands can be toxic (Hawser and Codd, 1992). Toxicity tests conducted with Trichodesmium sp. cells on the copepod Acartia tonsa demonstrated that intact cells were not toxic to A. tonsa, but the homogenized cells were (Guo and Tester, 1994). Thus the authors suggested that the alga contained one or more intracellular biotoxins.

Brackish waters can also harbour toxic cyanobacteria blooms. Some Australian estuaries and inlets (Huber and Hamel, 1985; Lenanton et al. 1985; Blackburn and Jones, 1995) and the Baltic Sea (Kononen, 1992) are examples of brackish areas where the toxic cyanobacterium Nodularia spumigena frequently forms blooms. Nodularin, the toxin associated with Nodularia spumigena which is hepatotoxic (Kiviranta et al. 1991; De Mott et al. 1991) may promote tumours with chronic exposure (Falconer, 1991). Given the discovery that some cyanobacterial toxins may stimulate tumour formation (Falconer, 1991; Carmichael, 1992), it is likely that there will be increasing awareness directed towards this type of phytoplankton bloom in coming years.

\subsubsection{Other Types of Toxic Bloom}

Toxic blooms of Prymnesiophytes are frequently reported to be a problem for aquaculture facilities. For example, a massive bloom of Chrysochromulina polylepis in the Skaggerak / Kattegat during May-June, 1988, caused havoc with salmon raising facilities along the Swedish Norwegian Coasts (Moestrup, 1994). This bloom also affected wild stocks of a number of different genera (Olsgard, 1993) and in addition to causing mortalities of mature animals, it has been shown that the presence of the phytoplankton inhibits the reproduction process in the ascidian, Ciona intestinalis and the mussel Mytilus edulis (Granmo et al. 1988). Thus Granmo et al. (1988) suggested that the phytoplankton bloom might have had long term effects in the affected area by reducing larval settlement and recruitment for these and possibly other species. Other plankton organisms were also shown to be affected by this Chrysochromulina bloom (Nielsen et al. 1990). Chrysochromulina leadbeatri caused mortalities in caged salmon among the northern Norwegian coast in 1991 and the two Prymnesium (P. patelliferum and P. parvum) have also caused mortalities in aquaculture facilities for salmon and rainbow trout (Aune et al. 1992; Meldahl et al. 1994, 1995).

There can be mechanical interaction between phytoplankton and the gills which leads to gill damage and ultimately suffocation of the fish. Diatoms are often implicated in such events (Bell, 1961; Taylor et al. 1985; Farrington, 1988; Rensel, 1993; Kent et al. 1995; Tester and Mahoney, 1995). The raphidophyte Heterosigma akashiwo presents a serious problem for aquaculture in many parts of the world including Japan, North America, Asia and New Zealand (Haigh and Taylor, 1990; Change et al. 1990; Black et al. 1991; Mackenzie, 1991; Qi et al. 1993; Honjo, 1994). Affected salmon shows signs of gill and intestinal pathology and death has been attributed to impairment of the gills' respiratory and osmoregulatory functions (Change et al. 1990). It has been suggested that the toxic effects elicited by this organism on salmon may be brought about by the formation of toxic concentrations of oxygen radical and hydrogen peroxide (Yang and Albright, 1994). Dinoflagellate 
Gyrodinium aureolum has been recognized as fish killer for many years (Tangen, 1977). Gill histopathology in affected fish has been reported to be similar to that observed in fish exposed to Heterosigma (Change et al. 1990).

It is now generally accepted that toxin production by G. aureolum is at least in some cases involved in mortalities caused by this organism (Boalch, 1983; Bullock et al. 1985; Heinig and Campbell, 1992). Jenkinson, (1989, 1993) suggested that Gymnodium aureolum and some other bloom forming flagellates may alter seawater characteristics through the production of extracellular organic material. This extracellular material should increase the viscosity of the medium surrounding the fish so that the energy expended in filtering water through the gills exceeds that which can be supported by the oxygen uptake. Phaecystis spp. are also considered to be harmful because they extrude protein-rich compounds that can be whipped into a stiff foam by wave action and which under certain hydrographic conditions can accumulate along beaches (Richardson, 1997).

A relatively new toxic dinoflagellate, Pfiesteria piscicida (Steidenger et al. 1996), was described by Burkholder et al. (1992). According to Burkholder et al. (1995) this dinoflagellate requires live finfish or their excrement in order to excyst and to release its potent neurotoxin. But more recently, research reports (Berry et al. 2002; Vogelbein et al. 2002) say that in the Pfiesteria shumwayee, the strain they have examined shows no signs of toxin. Instead, the single celled dinoflagellate alga kills by swarming over a fish and eating away its skin (Berry et al. 2002; Vogelbein et al. 2002; Kaiser, 2002; Rutherford, 2002).

\subsubsection{Marine Algal Toxins: Biochemistry and Molecular Biology}

The production of toxic compounds is a common, but not universal characteristic of harmful algal blooms (HABs). Only a few HAB toxins have been characterised and these are synthesised by only a limited number of algal species (Steidinger, 1993). Toxigenic algae may not have significant impacts on ecosystem processes as toxins affect viability, growth, fecundity and recruitment of a wide range of organisms.

The most widely known marine HAB toxins produce poisonous syndromes known as diarrhetic, paralytic, neurotoxic, and amnesic shellfish poisoning (DSP, PSP and ASP). Planktonic dinoflagellates synthesise the toxins associated with each of these poisoning events except that the ASP toxin, domoic acid is produced primarily by diatoms. Ciguatera, fish poisoning, another type of massive HAB toxin event is caused by benthic dinoflagellates.

From a chemical standpoint, the common marine HAB toxins are either alkaloids, poly ethers or substituted amines (Plumley, 1997). There are other toxins associated with HAB species such as superoxide and (or) hydroxyl radicals (Oda et al. 1992; Tanaka et al. 1992), lipoteichoic acids with hemagglutinin activity (Ahmed et al. 1995) and pentacyclic derivatives with a fuzed azine (Seki et al. 1995). Other toxic effects of HAB algae have been documented but the toxins remain to be elucidated (Burkholder and Glasgow, 1997). It is likely that many more marine HAB toxins will be identified and characterized as both utilization of marine resources and our ability to detect the toxins increases.

HAB toxins have complex chemical structures and they seem to be the end products of elaborate pathways and some of the enzymatic reactions are likely to entail highly unique and (or) specialized reactions (Plumley, 1997). Very little is known about the biochemistry of toxin synthesis. One of the difficulties is that HAB algae, which produce toxins are extremely difficult to culture (Shilo and Ashner, 1953) and remain largely resistant to most contemporary protocols routinely used with other microbes. At present rapid progress in understanding HAB algae at the molecular and biochemical levels is dependent on technological innovation. Some innovative analytical techniques developed promise to provide rapid and reliable detection of the causative organism and the toxins produced. Molecular probes are being applied to distinguish species-specific RNA and DNA sequences (Pierce and Kirkpatrick, 2001) for identification of HABs causing organisms.

\subsection{Increased Utilisation of Coastal Waters for Aquaculture}


With the increased problems of over fishing of coastal waters more and more countries are looking toward aquaculture as an alternative. Aquaculture operations act as sensitive 'bioassay systems' for harmful algal species and can bring to light the presence in water bodies of problem organisms known to exist there before. The increase in shellfish farming worldwide is leading to more reports of paralytic, diarrhetic and amnesic shellfish poisoning. On the other hand, increased finfish culture is drawing attention to algal species which can cause damage to the fishes delicate gill tissues (Taylor, 1988; Rensel et al. 1989). The diatoms long, hollow spines (setae) are studded with smaller barbs along their length. The setae can break off and penetrate the gill membranes of fish, with the smaller barbs preventing them from coming out (Tester and Mahoney, 1995; Rensel, 1993). Fish death may be caused by capillary haemorrhage, dysfunction of gas exchange at the gills, suffocation from an overproduction of mucus, or even from secondary infection of the damaged tissue (Bell, 1961, Bruno et al. 1989; Rensel, 1991; Yang and Albright, 1992, 1994).

A more widespread problem for fish farmers is the production by various algal groups of fatty acids or galactolipids (Bass et al. 1983; Bodennec et al. 1995) which damage the epithelial tissue of the gills. In experimental assay systems, these substances destroy red blood cells and therefore have been provisionally termed 'hemolysins' (Yasumoto et al. 1990). Algal species as diverse as the raphidophytes (Hetersigma akashiwo and Chatonella antique, the prymnesiophytes Chrysochromulina polylepis (Yasumoto et al. 1990) and Prymnesium Parvum (Kozaki et al. 1982) and the dinoflagellate Gymnodium mikimotoi (Arzul et al. 1995; Parrish et al. 1998) have been implicated (Change et al. 1990). The two prymnesiophyte flagellates Chrysochromulina. and Prymnesium produce substances that affect gill permeability leading to a disturbed ion balance (Yasumoto et al. 1990).

Toxicity by these species is promoted by phosphorous deficiency. A massive bloom $\left(60000 \mathrm{~km}^{2}\right.$, $10^{7}-10^{8}$ cells $\mathrm{l}^{-1}$ ) of Chrysochromulina polylepis occurred in May-June 1988 in the Skagerrak, the Kattegat, the Beltarea and the Sound between Denmark, Norway and Sweden (Rosenberg et al. 1988, Kaas et al. 1991). Fish deaths occurred due to damage of gill membranes which produced a lethal increase in the chloride concentration in the blood (Dahl and Tangen, 1993) and fish cages moved into less saline fjords were therefore less affected.

\subsection{Increase of Algal Blooms by Cultural Eutrophication}

Eutrophication as defined by Nixon 1995 "is an increase in the rate of supply of organic matter to an ecosystem". Eutrophication can occur via natural processes or as a result of human activities (cultural eutrophication). Correlations with eutrophication and human industrial development are of serious concern (Smayda, 1990, Sournia et al. 1991). A number of workers have suggested that there has been an increase in harmful blooms in recent years (Anderson, 1989; Smayda, 1990; Hallegraeff, 1993) and is often argued that the apparent increase in the occurrence of "harmful blooms" is linked to eutrophication. Indeed in some areas- especially those with limited water exchange such as fjords, estuaries and inland seas- there does seem to be good evidence for a stimulation of the number of algal blooms occurring by eutrophication. However, the relationship between the occurrence of harmful phytoplankton blooms and environmental conditions is complicated and anthropogenic perturbation of the environment is certainly not a pre-requisite for all harmful algal blooms (Richardson, 1997; Sellner et al. 2003). Thus, the occurrence of a harmful bloom may or may not have as one of its underlying causes a change in human activities or behavior.

Eutrophication from domestic, industrial and agricultural wastes can stimulate harmful algal blooms (Lam and Ho, 1989). In Hong Kong, this increase (mainly Gymnodium nagaskiense, Gonyaulx polygramma, Nocticula scintillaus and Prorocentrum minutum, shows a striking relationship with a 6 -fold increase in human population in Hong Kong and the concurrent 2.5 fold increase in nutrient loading mainly contributed by untreated domestic and industrial waste (Okaichi, 1989, Lam and Ho, 1989). There is considerable concern (Ryther and Dunstan, 1971, Officer and 
Ryther, 1980, Smayda, 1990) regarding the altered nutrient ratios in coastal waters. Improved wastewater treatment has been causing increases in the ammonia nitrate ratio of River Rhine discharge (Riegman and Noordeloos, 1991). The nutrient composition of treated wastewater is never the same as that of coastal waters in which it is being heavily discharged. Such altered nutrient ratios in coastal waters may favour blooms of nuisance flagellate species which replace the normal spring and autumn blooms of siliceous diatoms (Smayda, 1990).

The remarkable increase of foam producing blooms of the Prymnesiophyte Phaeocystis pouchetti which first appeared in Dutch Coastal waters in 1978 is probably the best studied example of this phenomenon (Lancelot et al. 1987). Algals species which are not normally toxic (Chrysochromulina, Nitzschia pungens .f. multiseries, Prymnesium parvum) may be rendered toxic when exposed to typical nutrient regimes (for example phosphate deficiency) resulting from cultural eutrophication (Shilo, 1981, Edvardsten et al. 1990, Bates et al. 1991). The 1998 bloom in the Kattegat of prymnesiophyte, Chrysochromulina polylepis, is not usual in terms of biomass but in terms of its species composition and toxicity, has been related to a change in the nutrient status from nitrogen to phosphorus limitation (Maestrini and Graneli, 1991). In the Black Sea, a long term decrease in the $\mathrm{Si}: \mathrm{P}$ ratio has been associated with an increase in the dinoflagellate blooms of Prorocentrum cordatum (Bodeanu and Usurelu, 1979). Changed patterns of land use, such as deforestation, can also cause shifts in phytoplankton species composition by increasing the concentrations of humic substances in land runoff. Acid precipitation can further increase the mobility of humic substances and trace metals in soils (Graneli and Moreira, 1990).

Agricultural run-off of phosphorus can also stimulate cyanobacterial blooms, for example Nodularia spumigena in the Baltic Sea and in the Peel Harvey Estuary, Australia. These species produce hepatotoxic peptides. Nodularia microcystis and neurotoxic alkaloids (Anabena aphanizomenon) can kill domestic and wild animals that drink from the shores of eutrophic ponds, lakes and reservoirs (Edler et al. 1985). Cyanobacteria also pose public health problems through the production of teratogens and tumour promoters, which are not acutely toxic (Carmicheal, 1989). The toxins accumulate in mussels and have been reported to contaminate drinking water. A neurotoxic factor has also been associated with some strains of the common marine, bloom forming tropical cyanobacterium Trichodesmium thiebautii (Hawser et al. 1991). While this organization can thrive under nutrient impoverished oceanic conditions, it is possible that coastal eutrophication can prolong or enhance bloom phenomena (Hallegraeff, 1993).

\subsection{Stimulation of Algal Blooms by Unusual Climatological Conditions}

The global change forcasts for the Period 1990-2100 in climate has been predicted to lead to a projected rise in temperature of $1.4-5.8^{\circ} \mathrm{C}$ with a $90 \%$ probability interval of $1.7-4.9 \%$ (IPCC 2001; Wigley and Raper, 2001). A direct consequence of global warming is thermal expansion of water and hence a rise in the sea level in 2100 by $0.1-0.9 \mathrm{~m}$ (IPCC, 2001). Photosynthesis and plankton growth are basic processes to the marine ecosystem, and in general both rates double when temperature increases by $10^{\circ} \mathrm{C}$ (Raven and Geider, 1988). The qualitative conclusion from investigations by Peperzak (2003) on the effects of climate change in the marine ecosystem indicate that the risk of harmful dinoflagellate and raphidophyte blooms will increase rather decrease due to climate change.

Increased temperature leads to decreased viscosity (Vogel, 1996), which theoretically leads to (i) increased nutrient diffusion towards the cell surface, which is important when interspecific competition for nutrients takes place (ii) increased sedimentation rates, which will be important for nonflagellate species such as diatom. At the present, the dinoflagellate Pyrodinium bahamense is confined to tropical mangrove fringed coastal water of the Atlantic or Indo-West Pacific. According to McMinn (1989), a survey of fossil occurrences of its resting cyst Polysphaeridium zokaryi found in records going back to Eocene 50 million years ago, recorded by Bujak and others, indicated a much wider range of distribution in the past. At present, the dinoflagellate does not extend further south than 
Papua New Guinea but in the Pleistocene, it ranged as far south as Sydney Harbour (McMinn, 1989). The first harmful implications of Pyrodinium blooms became evident in 1972 in Papua, New Guinea. Red brown water discolouration coincided with the fatal food poisoning of three children and mouse bioassays on shellfish from a house in the affected village subsequently established Pyrodinium bahamense as a source of paralytic shellfish poison (Maclean 1977). Maclean (1989) presented strong circumstantial evidence for a coincidence between Pyrodinium blooms and El Nino Southern Oscillation (ENSO) climatoligical events. Summer marine climate is dominated by the succession of periods of upwellings and other relaxation or downwellings. During the upwellings, water masses from as low as $60-70 \mathrm{~m}$ are brought close to the surface, indicated by the lowering of the temperature to $23-25^{\circ} \mathrm{C}$. These cool waters are also poor in oxygen $\left(\mathrm{O}_{2}\right)$ and rich in nutrients. Rich nutrient water is susceptible to trigger development of phytoplankton blooms (Claereboudt et al. 2001). Phytoplankton and other marine biota have relatively short life spans (roughly 1-3 days), under the right conditions they have the capacity to reproduce, or 'bloom' into exceptionally large numbers in a matter of days (Herring, 2002).

\subsection{Transport of Dinoflagellate Cysts in Ship's Ballast Water or Associated with the Transfer of Shellfish Stocks}

Dissemination of toxic species in the ballast water of commercial ships adds another concern (Hallegraeff and Bolch, 1991; Hallegraeff, 1993). Cargo vessel ballast water was first suggested as a vector in dispersal of non-indigenous marine plankton more than 90 years ago (Ostenfeld, 1908). The diatom Odontella sinesis, well known from the tropical and subtropical coasts of the Indo-Pacific, had not been reported in European waters until 1903, when it produced dense plankton blooms in the North Sea. Ostenfeld (1908) suggested that this species was introduced via the water or sediment contained in the ship's ballast tanks. Subsequently, Hallegraeff et al. (1990) confirmed this possibility by culturing the related diatom species Odontella aurita from a ballast water sample collected at the end of a voyage from Japan to Australia. The evidence of ballast water transfer of marine organisms other than microscopic algae is considerable and includes species of fish, crustaceans, polychaete worms and molluscs (Carlton, 1985).

The most effective measure to restrict spreading of dinoflagellate cysts via ship's ballast water would be to avoid ballasting during toxic dinoflagellate blooms in ports. Other options using heat or chemical treatment (chlorine, hydrogen peroxide) of ballast water either in hold or in onshore facilities have also been investigated (Rigby et al. 1991; Bolch and Hallegraeff, 1990).

Another anthropogenic vector for the dispersal of algae (especially their resting cysts) is with transfer of shellfish stocks containing phytoplankton in their digestive organs from one area to another (Hallegraeff, 1993).

\section{Bloom Dynamics}

\subsection{Bloom Initiation}

Generally, unusual wind/ weather/hydrographic conditions have been identified as factors preceding or accompanying the harmful algal blooms (Maestrini and Graneli, 1991; Rhodes et al. 1993). According to Fraga (1993) regions with coastal upwellings and river discharge areas are vulnerable to phytoplankton blooms. In some cases, wind, weather, tidal or other hydrographic conditions have been related to initiation of nearshore blooms by delivery of the organisms into the bloom region (Balch, 1981; Lindahl, 1983; Taylor et al. 1994). In some other cases, transport of phytoplankton blooms from offshore to inshore regions, longshore transport of blooms from one coastal region to another has also been documented (Franks and Anderson, 1992).

\subsection{Bloom Composition}


Individual phytoplankton species have different requirements and responses to the physical environment. Marine microalgae use inorganic nutrients such as nitrate, phosphates and sulphur, and convert them into the basic building blocks of living organisms- proteins, fats, carbohydrates. They also need trace elements such as silicon, iron and calcium (Kiørboe, 1993). The overall understanding of various phytoplankton species requirements and tolerances with respect to micronutrients is at a primitive stage. However, it is known that there are differences between species in terms of requirements for vitamin (Guillard et al. 1991; Graneli and Moreira, 1990; Graneli et al. 1993; Honjo, 1993) and trace metals (Price and Morel, 1991; Honjo, 1993).

\subsection{Bloom Maintenance}

Bloom maintenance requires the growth rate of the phytoplankton in a bloom to exceed the rate of loss of phytoplankton in a population. Phytoplankton loss usually occurs by grazing or through cell lysis sinking or advection away from the bloom site (Richardson, 1997).

Grazing impacts can be important in the development of harmful algal blooms. Limited grazing pressure often on toxic phytoplanktons may allow development of large biomasses of these phytoplankters. Grazing pressures can also be reduced by acting as a selection factor in phytoplankton species (Olsson et al. 1992) or by reduction in loss through advection (Crawford and Purdie, 1992) or by vertical migration of the phytoplankton in the water column.

The blooming organism can also be maintained by reduction of competition for limiting resources. If nutrients are limiting, then inhibition of other phytoplankters competing for the same nutrients will serve to optimize growth conditions for the bloom organism. Several harmful bloom forming species have been shown to have a repressing effect on other phytoplankton species, such as, Gyrodniium aureolum (Arzul et al. 1993); Heterosigma akashiwo (Honjo, 1993). Thus, more than one mechanism may be contributing towards maintenance of some phytoplankton blooms.

\subsection{Bloom Termination}

A phytoplankton bloom will terminate or decline when the loss factors exceed the increase factors. The immediate effect is usually a decrease in the growth rate of bloom forming phytoplankton species, brought about by a change in the environmental conditions, including light and / nutrients. The decaying phytoplankton cells can either sink out of the water column or lyse and release their contents to the surrounding water column (Richardson, 1997). Flagellate blooms are often degraded in the water column (Boekel et al. 1992), while diatom blooms often sink out of the water column (Cushing, 1992). Different diatoms have different sinking rates, which are probably influenced by cell volume and the physiological states, expressed as respiration rates (Waite et al. 1992).

According to Jackson (1990) a given phytoplankton population will grow exponentially until it reaches an equilibrium concentration : “critical concentration”. At this stage, growth and coagulation will balance. Applying the coagulation theory to phytoplanktons, it has been suggested that aggregation may be an important mechanism in terms of sudden disappearance of diatom blooms (Jackson, 1990; Jackson and Lochmann, 1992). The phytoplankton cells are believed to possess a certain degree of adhesiveness or stickiness that allows them to aggregate or stick together (Kiørboe et al. 1990). Under laboratory conditions, different phytoplankton species exhibit different degrees of “stickiness” (Kiørboe et al. 1990). Moreover, age (physiological state) can influence stickiness within an individual species. A better understanding of these mechanisms will help to elucidate the bloom dynamics.

\section{Summary and Conclusions}

Marine phytoplankton blooms occur intermittently, within $100 \mathrm{~km}$ of coastal regions near all the major continents. The common denominators associated with phytoplankton blooms are (a) seed 
population of organisms; (b) proper chemical environment of organic and inorganic nutrients; and (c) suitable physical and hydrographic conditions for concentration and maintenance of nutrient organisms. Phytoplankton blooms are natural phenomena that develop over various scales of space and time including the massive, sudden and local outbursts of one or more species. Such phenomena have also been termed "red tides", "brown tides", "colored waters" or "discolored waters". There are about 4000 different species which constitute the world's flora. Approximately 6\% (about 200 species) have been indicated to cause red tides or are regarded as harmful. About $2 \%$ of the world's phytoplankton are implicated in toxin production. According to a number of workers, there has been a considerable rise in harmful algal blooms due to anthropogenic activities in recent years. These activities include eutrophication, distribution and transport of harmful species from one region to another via ballast water or in connection with aquacultural activities. Despite several common features HABs are very diverse in terms of causative organisms, dynamics of blooms and type of blooms.

\section{References}

ADLEMAN, W.J., JR., FOHLMEISTER, J.F., SASNER, J.J., JR. and IKAWA, M. 1982. Sodium channels blocked by aphantoxin obtained from the blue-green alga. Aphanizomenon flos-aquae. Toxicon. 23: 513-516.

AHMED, M.S., ARAKAWA, O. and ONOUE, Y. 1995. Toxicity of cultured Chatonella marina. In: Harmful Marine Algal Blooms (Lassus, P., Arzul, G., Erard-Le-Denn, E., Gentien, P. and Marcillou-Le-Baut, C., eds.) pp 499-504, Paris, Lavoisier.

ALLEN, W.E. 1946. "Red Water" in La Jolla bay in 1945. Trans. Amer. Microsc. Soc. 65 (2): 149153.

ANDERSEN, D.M. 1989. Toxic algal blooms and red tides: A global perspective. In: Red Tides: Biology, Environmental Science and Toxicology. Proc. $1^{\text {st }}$ Int. Symp. on Red Tides. pp. 11-16, Elsevier.

ANDERSON, D.M., WHITE, A.W. and BADEN, D.G. 1985. Toxic Dinoflagellates. pp. 561. Elsevier, New York.

ANDERSON, D.M. 1989. Toxic algal blooms and red tide: a global perspective. In: Red Tides: Biology, Environmental Science and Toxicology. (Okaichi, T., Anderson, D.M. and Nemoto, T., eds.) pp. 11-16. Elsevier Science Publishing Co., New York.

ANDERSON, D.M. and WHITE, A.W. 1992. Marine biotoxins at the top of the food chain. Oceanus. 35: 55-61.

ANDERSON, D.M., KULIS, D.M., SULLIVAN, J.J., HALL, S. and LEE, C. 1990. Dynamics and physiology of saxitoxin production by the dinoflagellates Alexandrium spp. Mar. Biol. 104: 511524.

ANDERSON, D.M. and LOBEL, P.S. 1987. The continous enigma of ciguatera. Biol. Bull. 172: 89107.

ARZUL, G., ERARD-LE-DENN, E., VIDEAU, C., JEGOU, A.M. and GENTIEN, P. 1993. Diatoms growth repressing factors during an offshore bloom of Gyrodinium cf. aureolum. In: Toxic Phytoplankton Blooms in the Sea. (Smayda, T.J. and Shimizu, Y., eds.) pp. 719-724. Elsevier, Amsterdam.

ARZUL, G., TURKI, S., HAMZA, A., DANIEL, P. and MERCERON, M. 1995. Fish kills induced by phycotoxins. Toxicon. 33: 11-19.

AUNE, T., SKULBERG, O.M. and UNDERDAL, B. 1992. A toxic phytoflagellate bloom of Chrysochromulina cf. leadbeateri in coastal waters in the north of Norway, May-June 1991. Ambio. 21: 471-474. 
AUNE, T. and YNDESTAD, M. 1993. Diarrhetic shellfish poisoning In: Algal Toxins in Seafood and Drinking Water. (Falconer, I.R., ed.) pp. 87-104. London: Academic Press.

BADDYR, M. 1992. PSP in Morocco. In: Harmful Algae News, no. 2. (Wyatt, T. and Y. Pazos, Y., ed.) p.5,UNESCO, Paris, France.

BADEN, D.G. and MENDE, T.J. 1982. Toxicity of two toxins from the Florida red tide marine dinoflagellate Ptychodiscus brevis. Toxicon. 20: 457-461.

BADEN, D.G. 1983. Marine food-borne dinoflagellate toxins. Int. Rev. Cytol. 82: 99-150.

BADEN, D.G. 1989. Brevetoxin analysis. Toxic dinoflagellates and marine mammal mortalities. pp. 47-52, Technical Reports. Woods Hole Oceanographic Institution.

BADEN, D.G. 1995. Structure/function relationships of the brevetoxins:interferences from molecular modeling, organic chemistry, and specific receptor binding protocols In: Harmful Marine Algal Blooms. (Lassus, P., Arzul, G., Erard-Le-Denne, E., Gentien, P. and Marcaillou-Le-Baut,C., eds.) pp. 257-266, Lavoiser/ Intercept, Paris, France.

BALECH, E. 1995. The genus Alexandrium Halim (Dinoflagellata) Sherkin Island Marine Section, County Cork, Ireland. pp.151.

BALCH, W.M. 1981. An apparent lunar tidal cycle of phytoplankton blooming and community succession in the Gulf of Maine. J. Exp. Mar. Biol. Ecol. 55: 65-77.

BASS, E.L., PINION, J.P. and SHARIF, M.E. 1983. Characteristic of a hemolysin from Gonyaulax monilata Howell. Aquat. Toxicol. 2: 15-22.

BATES, S.S. 2000. Domoic acid producing diatoms: another genus added. J. Phycol. 36: 978-985.

BATES, S.S., BIRD, C.J., DeFRIETAS, A.S.W., FOXALL, R., GILGAN, M., HANIC, L.A., JOHNSON, G.R., McCULLOUGH, A.W., ODENSE, P., POCKLINGTON, R., QUILLIAM, M.A., SIM, P.G., SMITH, J.C., SUBBA RAO, D.V., TODD, E.C.D., WALTER, J.A. and WRIGHT, J.L.C. 1989. Pennate diatom Nitzschia pungens as the primary source of domoic acid, a toxin in shellfish from eastern Edward Island, Canada. Can. J. Fish. Aquat. Sci. 46: 12031215.

BATES, S.S, DeFREITAS, A.S.W., MILEY, J. E., POCKLINGTON, R., QUILLIAM, M.A., SMITH, J.C. and WORMS, J. 1991. Controls on domoic acid production by diatom Nitzschia pungens $f$. multiseries in culture: nutrients and irradiance. Can. J. Fish. Aquat. Sci. 48: 1136-1144.

BATES, S.S., DOUGLAS, D.J. and HOMER, R.A. 1995. Enhancement of domoic acid production by reintroducing bacteria to axenic cultures of the diatom Pseudo-nitzschia multiseries. Nat. Toxins. 3: $428-435$.

BELL, J.R. 1961. Penetration of spines from a marine diatom into the gill tissue of lung cod (Ophiodon elongatus). Nature. 192: 279-280

BERRY, J.P, REECE, K.S., REIN, K.S., BADEN, D.E., HAAS, L.W., RIBER, W.L., SHIELDS, J.D., SYNDER, R.V., VOGELBEIN, W.K. and GAWLEY, R.E. 2002. Are Pfiesteria species toxigenic? Evidence against production of ichthyotoxins by Pfiesteria shumwayae. Proc. Natl. Acad. Sci. 99(17): 10970-10975.

BLACK, E.A., WHYTE, J.N.C., BAGSHAW, J.W. and GINTHER, N.G. 1991. The effects of Heterosigma akashiwo on juvenile Oncorhynchus ishawytscha and its implications for fish culture. J. Appl. Ichthy. 7: 168-175.

BLACKBURN, S.I. and JONES, G.J. 1995. Toxic Nodularis spumigena Mertens blooms in Australian waters- a case study from Orielton Lagoon, Tasmania. In: Harmful Marine Algal Blooms (Lassus, P., Arzul, G., Erard, E., Gentien, P. and Marcaillou, C., eds.) pp.121-126. Lavoiser/ Intercept, Paris France.

BOALCH, G.T. 1983. Recent dinoflagellate blooms in Plymouth area. Br. Phycol. J. 18: 200-291.

BOALCH, G.T. and HARBOUR, D.S. 1977. Unusual diatom off the Coast of South west England and its effects on fishing. Nature. 269: 687-688. 
BODEANU, N. and USURELU, M. 1979. Dinoflagellate blooms in Romanian Black Sea coastal waters In: Toxic Dinoflagellate Blooms (Taylor, D.J. and Seliger, H.H., eds.) pp. 151-154. Elsevier, Amsterdam.

BODENNEC, G., GENTIEN, P., PARISH, C.C., ARZUL, G., YOUENOU, A. and CRASSOUS, M.P. 1995. Production of suspected lipid phycotoxins by Gymnodium cf. nagaskiense in batch cultures. In: Harmful Marine Algal Blooms (Lasus, P., Arzul, G., Erard-Le-Denn, E., Gentien, P., Marcaillou-Le-Baut, eds.) pp. 407-412. Lavoiser, Paris.

BOEKEL, W.H.M. van, HANSEN, F.C., RIGMAN, R. and BAK, R.P.M. 1992. Lysis-induced decline of a Phaeocystis spring bloom and coupling with the microbial food web. Mar. Ecol. Prog. Ser. 81: 269-276.

BOLCH, C.J. and HALLEGRAEFF, G.M. 1990. Dinoflagellate cysts in recent marine sediments from Tasmania, Australia. Bot. Mar. 33: 173-192.

BOMBER, J.W. 1991. Toxicogenesis in dinoflagellates: genetic and physiological factors. In: Ciguatera Seafood Poisoning. ( Miller, D.M., ed.) pp.135-170. CRC Press, Boca Raton.

BRUNO, D.W., DEAR, G. and SEATON, D.D. 1989. Mortality associated with phytoplankton blooms among farmed Atlantic salmon, Salmo salar L. in Scotland. Aquaculture. 78: 217-222.

BULLOCK, A.M., TURNER, M.F. and GOWEN, R.J. 1985. The toxicity of Gyrodinium aureolum. Bull. Mar. Sci. 37: 763-764.

BURKHOLDER, J.M., NOGA, E.J., HOBBS, C.H., GLASGOW, H. B. and SMITH, S.A. 1992. New "phantom" dinoflagellate is the causative agent of major estuarine fish kills. Nature. 358: 407410.

BURKHOLDER, J.M. and GLASGOW, H.B.Jr. 1995. Interaction of a toxic estuarine dinoflagellate with microbial predators and prey. Arch. Protistenked. 145: 177-188.

BURKHOLDER, J.M. and GLASGOW, H.B. Jr. 1997. Pfiesteria piscida and other Pfiestera-like dinoflagellates, behavior, impacts and environmental controls. Limnol. Oceanogr. 42: 10521075.

BURKHOLDER, J.M, MALLIN, M.A. and GLASGOW, H.B. 1999. Fish kills, bottom water hypoxia, and the toxic Pfiesteria complex in the Neuse River and estuary. Mar. Ecol. Prog. Ser. 179: $301-310$.

BURKHOLDER, J.M., GLASGOW, H.B., DEAMER-MELIA, N., SPRINGER, J., PARROW, M.W., ZHANG, C. and CANCELLIER, P. 2001. Overview and present status of the toxic Pfiesteria complex (Dinophyceae). Phycologia. 40: 186-214.

CARLTON, J.T. 1985. Transoceanic and interoceanic dispersal of coastal marine organisms: the biology of ballast water. Ocean Mar. Biol. Ann. Rev. 23: 313-374.

CARMICHAEL, W.W.1981. The Water Environment: Algal Toxins and Health. pp 491. Plenum Press, New York.

CARMICHAEL, W.W. 1986. Algal toxins. Adv. Bot. Res. 12: 47-101.

CARMICHAEL, W.W. 1996. Toxic microcystis and the environment. In: Toxic Microcystis. (Watanabe, M.F., Harada, K.-I., Carmichael, W.W. and Fujiki, H., eds.) pp.1-11. Boca Raton, CRC Press.

CARMICHAEL, W.W. 1992. Status report on Planktonic Cyanobacteria (Blue green Algae) and their toxins. Ecological Research Service US Environmental Protection Agency. pp. 149.

CARMICHAEL, W.W. 1989. Freshwater cyanobacteria (blue-green algae) toxins, In: Natural Toxins (Ownby, C.L. and Odell, G.V., eds.) Proceedings $9^{\text {th }}$ World Congress on Animal, Plant and Microbial Toxins. pp. 3-16. Pergamon Press, New York.

CEMBELLA, A.D., SULLIVAN, J.J., BOYER, G.L., TAYLOR, F.J.R. and ANDERSEN, R.J. 1987. Variations in paralytic shellfish toxin composition within the Protogonyaulax tamarensis/ catanella species complex; red tide dinoflagellates. Biochem. Syst. Ecol. 15: 171-186. 
CHANGE, F.H., ANDERSON, C. and BOUSTEAD, N.C. 1990. First record of a Heterosigma (Raphidophyceae) bloom with associated mortality of cage reared salmon in Big Glory Bay, New Zealand. N. Z. J. Mar. FW. Res. 24: 461-469.

CHEN, C.Y. and CHOU, H-N. 2001. Ichthyotoxicity studies of milkfish Chanos chanos fingerlings exposed to a harmful dinoflagellate Alexandrium minutum. J. Exp. Biol. Ecol. 262: 211-219.

CHEN, H. and QI, S. 1991. The feeding and vegetative reproduction diurnal rhythm of Noctiluca scintillans. J. Jinan. Univ. 12: 104-107.

CHINAIN, M., FAUST, M.A. and PAUILLAS, S. 1999. Morphology and molecular analyses of three toxic species of Gambierdiscus (Dinophyceae): G. Pacifus sp. nov., G. australes sp. nov., and G. polynesiensis, sp. nov. J. Phycol. 35: 1282-1296.

CHOU, H.N., SHIMIZU, Y., van DUYNE, G.D. and CLARDY, J. 1985. Two new polyether toxins of Gymnodium breve (Ptychodiscus brevis). In: Toxic Dinoflagellates (Anderson, D.M., White, A.W. and Baden, D.G., eds.) pp. 305-308. Elsevier, New York.

CLAEREBOUDT, M., HERMOSA, G. and McLEAN, E. 2001. Possible causes of massive fish kills in the Gulf of Oman. In: Proc $1^{\text {st }}$ International Conference on Fisheries, Aquaculture and Environment in the NW Indian Ocean (Claereboudt, M., Goddard, S., Al Oufi, H. and Mellwan, E., eds.) pp.123-132. Sultan Qaboos University, Muscat, Sultanate of Oman.

COLWELL, R.R. 1983. Biotechnology in the marine sciences. Science. 222: 19-24.

CRAWFORD, D.W. and PURDIE, D.A. 1992. Evidence for avoidance of flushing from an estuary by a planktonic, phototrophic ciliate. Mar. Ecol. Prog. Ser. 81: 269-276.

CUSHING, D.H. 1992. The loss of diatoms in the spring bloom. Philosophical transactions of the Royal Society. 335: 237-246.

DAHL, E. and TANGEN, K. 1993. 25 years experience with Gyrodinium aureolum in Norwegian waters In: Toxic Phytoplankton Blooms in the Sea. (Smayda, T.J., Shimizu, Y., eds.) vol. 3, pp. 15-21, Elsevier Amsterdam, The Netherlands.

DALE, B., MADSEN, A., NORDBERG, K. and THORSEN, T.A. 1993. Evidence for prehistoric and historic "blooms" of the toxic dinoflagellate Gymnodium catenatum in the Kattegat-Skagerrak region of Scandinavia. In: Toxic Phytoplankton Blooms in the Sea. (Smayda, T.J. and Shimizu, Y. eds.) pp. 53-57, Elsevier, Amsterdam, The Netherlands.

DAUGBJERG, N., HANSEN, G., LARSEN, J. and MOESTRUP, O. 2000. Phylogeny of some of the major genera of dinoflagellates based on ultrastructure and partial LSU rDNA sequence data, including the erection of three new genera of unarmoured dinoflagellates. Phycologia. 39: 3023167.

DeMOTT, W.R., ZHANG, Q-X. and CARMICHAEL, W.W. 1991. Effects of toxic cyanobacteria and purified toxins on the survival and feeding of a copepod and three species of Daphnia. Limnol. Oceanogr. 36: 1346-1357.

DESBIENS, M. and CEMBELLA, A.D. 1995. Occurrence and elimination kinetics of PSP toxins in the American lobster (Homarus americanus). In: Harmful Marine Algal Blooms. (Lassus, P., Arzul, G., Erard-Le-Denn, E.,Gentien, P. and Marcaillou, Le-Baut, C., eds.) pp. 433-438. Lavoiser/ Intercept, Paris France.

EDLER, L., FERNO, S., LIND, M.G., LUNDBERG, R. and NILSSON, P.O. 1985. Mortality of dogs associated with a bloom of the cyanobacterium Nodularia spumigena in the Baltic Sea. Ophelia. 24: 103-109.

EDVARDSEN, B., MOY, F. and PAASCHE, E. 1990. Hemolytic activity in extracts of Chrysochromulina polylepis grown at different levels of selenite and phosphate. In: Toxic Phytoplankton. (Graneli, E., Sundstrom, B., Edler, L. and Anderson, D.M., eds.) pp. 284-289, Elsevier Science Publishing Co., New York.

EILERSTEN, H.C. and RAA, J. 1994. Phytoplankton toxins in seawater. In: $3^{\text {rd }}$ Marine Biotechnology Conference. Tromso International University. Norway, p69. 
ELBRACHTER, E. 1990. Phytoplankton toxin production. Water Poll. Res. 18: 213-223.

ENDEAN, R., GRIFFITH, J.K., ROBBINS, J.J. and MONKS, S.A. 1993. Multiple toxins in the specimen of the narrow-barred Spanish mackerel Scomberomorous commersoni. Toxicon. 31: 195-204.

ENDO, M., SAKAI, T. and KUROK, A. 1985. Histological and histochemical changes in the gills exposed to raphidohycean flagellate Chatonella marina. Mar. Biol. 87: 193-197.

ENDO, M., ONOUE, Y. and KUROKI, A. 1992. Neurotoxin induced cardiac disorder and its role in the death of fish exposed to Chatonella marina. Mar. Biol. 112: 371-376.

FALCONER, I.R. 1991. Tumour promotion and liver injury caused by oral consumption of cyanobacteria. Environ. Toxicol. Water Quality. 6: 177-184.

FARRINGTON, C.W. 1988. Mortality and pathology of juvenile Chinook salmon Oncorhynchus tshawytscha and chum salmon Oncorhynchus keta exposed to cultures of the marine diatom Chaetoceros convolutus. Alaska Sea Grant Report, pp80.

FAUST, M.A. 1995. Observation of sand-dwelling toxic dinoflagellates (Dinophyceae) from widely differing sites, including two new species. J. Phycol. 31: 996-1003.

FISTAROL, G.O., LEGRAND, C., RENGEFORS, K. and GRANELI, E. 2004. Temporary cyst formation in phytoplankton: a response to allelopathic competition. Environ. Microbiol. 6 (8): 791-798.

FRAGA, S. 1993. Harmful algal blooms in relation to wind induced coastal upwelling and river plumes. Inernational Council Meeting Paper L: 38 (mimeo).

FRANKS, P.J.S. and ANDERSON, D.M. 1992. Alongshore transport of a toxic phytoplankton bloom in buoyancy current: Alexandrium tamarense in the Gulf of Maine. Mar. Biol. 112: 153.

FREMY, J.M. 1991. Marine biotoxins: a short overview. In: Proceedings of Symposium on Marine Biotoxins, Centre National d'Estudes Veteret Alimentaires.pp. 3-6. Maisons, Alfort, Paris.

GAINEY, L.F. and SHUMWAY, S.E. 1991. The physiological effect of Aureococcus anophagefferens ("brown tide") in the lateral cilia of bivalve mollusks. Biol. Bull. (Marine Biological Laboratory, Woods Hole). 181: 298-306.

GALLAGER, S.M., STOECKER, D.K. and BRICELJ, V.M. 1989. Effects of the brown tide alga on growth, feeding physiology and locomotive behavior of scallop larvae (Argopecten irradens) In: Novel Phytoplankton Blooms. (Cosper, E.M., Bricelj, V.M. and Carpenter, E.J., eds.) pp. 511541, Springer, Berlin, Germany.

GERACI, J.R., ANDERSON, D.M., TIMPER R.J. and STAUBIN, G.A. 1989. Humpback whales (Megaptera novaeangliae) fatally poisoned by dinoflagellate toxin. Can. J. Fish. Aquatic. Sci. 46: 1895-1898.

GOSSELIN, S., FORTIER, L. and GAGNE, J.A. 1989. Vulnerability of marine fish larvae to the toxic dinoflagellate Protogonyaulax tamarensis. Mar. Ecol. Prog. Ser. 57: 1-10.

GRANELI, E., CARLSSON, P., OLSSON, P., SUNDSTROM, P., GRANELI, W. and LINDAHL, O. 1989. From anoxia to fish poisoning. The last ten years of phytoplankton blooms in Swedish marine waters. In: Novel Phytoplankton Blooms. Eds. (Cosper, E.M., Bricelj, V.M. and Carpenter, E.J., eds.) pp. 407-427, Springer.

GRANELI, E. and MOREIRA, M.O. 1990. Effects of river water of different origin on the growth of marine dinoflagellate and diatoms in laboratory cultures. J. Exp. Mar. Biol. Ecol. 136: 89-106.

GRANELI, E., PAASCHE, E. and MAESTRINI, S.Y. 1993. Three years after the Chrysochromulina polylepis bloom in Scandinavian waters in 1988: some conclusions of recent research and monitoring. In: Toxic Phytoplankton Blooms in the Sea. (Smayda T.J. and Shimizu Y. eds.) pp. 23-32. Elsevier, Amsterdam.

GRANMO, A., HAVENHAND, J., MAGNUSSON, K. and SVANE, I. 1988. Effects of the planktonic flagellate Chrysochromulina polylepis Manton et Park on fertilization and early 
development of the ascidian Ciona intestinalis (L.) and the blue mussel Mytilus edulis L. J. Exp. Mar. Biol. Ecol. 124: 65-71.

GUILLARD, R.R., KELLER, M.D., O’KELLY, C.J. and FLOYD, G.L. 1991 Pycnococcus provasolii gen. et. sp. nov. a coccoid prasinoxanthin-containing phytoplankter from the western North Atlantic and Gulf of Mexico. J. Phycol. 27: 39-47.

GUO, C. and TESTER, P.A. 1994. Toxic effect of the bloom-forming Trichodesmium sp. (Cyanophyta) to the copepod Acartia tonsa. Nat. Toxins. 2: 222-227.

HAIGH, R. and TAYLOR, F.J.R. 1990. The distribution of potentially harmful phytoplankton species in the north Strait of Georgia, British Columbia. Can. J. Fish. Aquat. Sci. 47: 2339-2350.

HALIM, Y. 1960. Alexandrium minutum nov.g.nov.sp. dinoflagellate provocant des eaux rouge'. Vie. Et. Millieu. 11: 102-105.

HALL, S., STRICHARTZ, G., MOCZYDOLOWSKI, E., RAVINDRAN, A. and REICHARDT, P.B. 1990. The Saxitoxins. In: Marine Toxins, Origin, Structure and Molecular Pharmacology. (Hall, S., and Strichartz, G., eds.) pp. 29-65. ACS Symposium Series 418, American Chemical Society. Washington DC.

HALLEGRAEFF, G.M., BOLCH, C.J., BRYAN, J. and KOERBIN, B. 1990. Microalgal spores in ships' ballast water: a danger to aquaculture. In: Toxic Marine Phytoplankton. (Graneli, E., Sundstrom, B., Edler, L. and Anderson, D.M., eds.) pp. 475-478. Elsevier Science Publishing Co., New York.

HALLEGRAEFF, G.M. and BOLCH, C.J. 1991. Transport of toxic dinoflagellate cysts via ships' ballast water. Mar. Poll. Bull. 22: 27-30.

HALLEGRAEFF, G.M., BOLCH, C.J., BLACKBURN, S.I. and OSHIMA, Y. 1991. Species of the toxigenic dinoflagellate genus Alexandrium in South eastern Australian waters. Bot. Mar. 34: 578-587.

HALLEGRAEFF, G.M. 1993. A review of harmful algal blooms and their apparent global increase. Phycologia. 32 (2): 79-99.

HALLEGRAEFF, G.M. 1995. Harmful algal blooms: a global overview. In: Manua of Marine Microalgae. (Hallegraeff, G.M.,Anderson, D.M. and Cembella, A., eds.) pp. 1-22 Paris, UNESCO.

HANSEN, G., DAUGBJERG, N. and HENRIKSEN, P. 2000. Comparative study of Gymnodium nikimotoi and Gymnodium aureolum comb nov. (= Gyrodinium aureolum) based on morphologic pigment composition and molecular data. J. Phycol. 36: 394-410.

HARRIS, G.P. 1986. Phytoplankton ecology. Chapman and Hall. London, xi- p384.

HASHIMOTO, Y. 1979. Marine Toxins and other Bioactive Marine Metabolites. Japan Scientific Societies Press, pp. 369, Tokyo.

HASLE, G.R. and SYVERTSEN, E.E. 1996. Marine diatoms In: Identifying Marine Diatoms and Dinoflagellates. (Thomas, C., ed.) pp. 5-385. San Diego, Academic Press.

HAWSER, S.P., CODD, G.A., CAPONE, D.G. and CARPENTER, E.J. 1991. A neurotoxic factor associated with the bloom-forming cyanobacterium Trichodesmium. Toxicon. 29: 277-278.

HAWSER, S.P. and CODD, G.A. 1992. The toxicity of Trichodesmium blooms from Carribean waters In: Marine Pelagic Cyanobacteria: Trichodesmium and other Diazotrophs. (Carpenter, E.J., Capone, D.G., Reuter, J.G., eds.) pp.319-329, Kluwer, Dordrecht, The Netherlands.

HEINIG, C.S. and CAMPBELL, D.E. 1992. The environmental context of a Gyrodinium aureolum bloom and shellfish kill in Maquoit Bay, Maine, September, 1988. J. Shellfish Res.11: 111-122.

HERRING, D. 2002. Fish kill in the Gulf of Oman. http://earth observatory.nasa.gov/study/oman/.

HO, K.C. and HODGKINS, I.J. 1992. Severe fishkill in Hong Kong caused by Noctiluca scintillans. Red Tide Newslett. 5:1-2. 
HO, M.S. and ZUBKOFF, P.L. 1979. The effects of Cochlodinium heterolobatum bloom on the survival and calcium uptake by larvae of the American oyster Crassostrea virginica. In: Toxic Dinoflagellate Blooms. Proc. $2^{\text {nd }}$ Int. Conf. pp.409-412. Elsevier.

HOFMAN, R.J. 1989. Actions necessary to assess the possible impacts of marine biotoxins on marine mammals. In: Toxic Dinoflagellates and Marine Mammal Mortalities. Technical Report, Woods Hole Oceanographic Institute, MA, USA, pp53-55.

HONG, J. and HUANG, X. 1989. Analysis and preliminary research of red tide frequent area in changing estuary and adjacent sea area. J. Jinan. Univ., Special issue on Red Tide. pp. 40-51.

HONJO, T. 1993. Overview on bloom dynamics and physiological ecology of Heterosigma akashiwo In: Toxic Phytoplankton Blooms in the Sea. (Smayda, T.J. and Shimizu, Y., eds.) pp. 33-41. Elsevier, Amsterdam.

HONJO, T. 1994. The biology and prediction of representative red tides associated with fish kills in Japan. Jpn. Rev. Fish. Sci. 2: 225-253.

HORNER, R., POSTEL, J.R. and RENSEL, J.E. 1990. Noxious phytoplankton blooms in western Washington waters. A review, In: Toxic Marine Phytoplankton, pp769-773. Proc $4^{\text {th }}$ Int. Conf. Elsevier.

HORNER, R., GARRISON, D.L. and PLUMLEY, F.G. 1997. Harmful algal blooms and red tide problems on the US west coast. Limnol. Oceanogr. 4: 1076-1088.

HU, T., de FREITAS, A.S., DOYLE, J., JACKSON, D., MARR, J., NIXON, E., PLEASANCE, S., QUILLIAM, M.A., WALTER, J.A. and WRIGHT, J.L.C. 1996. New DSP toxin derivative isolated from toxic mussels and the dinoflagellates, Prorocentrum lima and Prorocentrum concavum. J. Nat. Prod. 59: 1010-1014.

HUBER, A.L. and HAMEL, K.S. 1985. Phosphates activities in relation to phosphorous nutrition in Nodularia spumigena (cyanobactericeae). 1.Field Studies. Hydrobiologia. 123: 145-152.

HUNTLEY, M.E., STYKES, P., ROHAN, S. and MARIN, V. 1986. Chemically mediated rejection of dinoflagellate prey by the copepods Calanus pacifus and Paracalanus parvus: mechanism, occurrence and significance. Mar. Ecol. Prog. Ser. 28: 105-120.

IANORA, A., POULET, S.A. and MIRALTO, A. 1995. A comparative study of the inhibitory effects of diatoms on the reproductive biology of the copepod Acartia clausi. Mar. Biol. 121: 533-539.

ICES (1984). Report of the ICES Special Meeting on the causes, dynamics and effects of exceptional marine blooms and related events. International Council Meeting Paper, 1984/E, 42, (mimeo).

IPCC. 2001. A report of working group 1 of the Intergovernmental Panel on Climate Change. Summary for Policymakers and Tech. Summary http://www.ipcc.ch/pub/.

IVES, J.D. 1985. The relationship between Gonyaulax tamarensis cell toxin levels and copepod ingestion levels. In: Toxic Dinoflagellates. (Anderson; D.M., White, A.W. and Baden, D.G., eds.) pp. 413-418, Elsevier, New York.

IVES, J.D. 1987. Possible mechanisms underlying copepod grazing responses to levels of toxicity in red tide dinoflagellates. J. Exp. Mar. Biol. Ecol. 112: 131-145.

JACKSON G.A. 1990. A model of the formation of marine algal flocs by physical coagulation processes. Deep-Sea Research. 37: 1197-1211.

JACKSON, G.A. and LOCHMANN, S.E. 1992. Effect of coagualtion on nutrient and light limitation of an algal bloom. Limnol .Ocean. 37: 77-89.

JENKINSON, I.R. 1989. Increases in viscosity may kill fish in some blooms. In: Red Tides: Biology, Environmental Science and Toxicology. (Okaichi, T., Anderson, D.M. and Nemoto, T., eds.) pp. 435-438, Elsevier, New York, Amsterdam.

JENKINSON, I.R. 1993. Viscosity and elasticity of Gyrodinium aureolum and Noctiluca scintillans exudates, in relation to mortality of fish and damping of turbulence. In: Toxic Phytoplankton Bloom in the Sea, vol. 3. (Smayda, T.J. and Shimizu,Y., eds.) pp. 757-762. Elsevier, Amsterdam. 
JONES, J.B. and RHODES, L.L. 1994. Suffocation of pilchards Sardinops sagax by a green microalgal bloom in Wellington Harbour, New Zealand. N. Z. J. Mar. FW. Res. 28: 379-383.

KAAS, H., LARSEN, J., MOHLENBERG, F. and RICHARDSON, K. 1991. The Chrysochrmulina polylepis bloom in the Kattegat (Scandinavia) May-June, 1988. Distribution, primary production and nutrient dynamics in the late stage of the bloom. Mar. Ecol. Prog. Ser. 79: 151-161.

KAISER, J. 2002. The Science of Pfiesteria: Elusive, Subtle, and Toxic. Science. 298: 346-349.

KAO, C.Y. and WALKER, S.E. 1982. Active group of saxitoxin and tetrodotoxin as deduced from actions of saxitoxin analogues on frog muscle and squid axon. J. Physiol. 323: 619-637.

KENT, M.L., WHYTE, J.N.C. and La TRACI, C. 1995. Gill lesions and mortality in seawater pen reared Atlantic salmon Salmo salar associated with a dense bloom of Skeletonema costatum and Thalassiosira species. Dis. Aquat. Org. 22: 77-81.

KIM, H.G., PARK, J.S., LEE, S.G. and AN, K.H. 1993. Population cell volume and carbon content in non specific dinoflagellate blooms In: Toxic Phytoplankton blooms in the sea. (Smayda, T.J. and Shimizu, Y., eds.) pp.769-713. Elsevier, Amsterdam.

KIØRBOE, T.; ANDERSEN, K.P. and DAM, H. 1990. Coagulation efficiency and aggregate formation in marine phytoplankton. Mar. Biol. 107: 235-245.

KIØRBOE, T. 1993. Turbulence, phytoplankton cell size and the structure of pelagic food webs. Adv. Mar. Biol. 29: 1-72.

KIVIRANTA , J., SIVONEN, K., NIEMALA, S.I. and HUOVINEN, K. 1991. Detection of toxicity of cyanobacteria by Artemia salina bioassay. Environ. Toxicol. Water Qual. 6: 423-436.

KONONEN K. 1992. Dynamics of the Toxic Cyanobacterial Blooms in the Baltic Sea. Finnish Marine Research, No.261. Helsinki, Finland.

KOZAKI, H., OSHIMA, Y. and YASUMOTO, T. 1982. Isolation and structural elucidation of hemolysin from the phytoflagellate Prymnesium parvum. Agric. Biol. Chem. 46: 233-236.

LAM, C. 1988. Recent red tide events in Hong Kong fish kills and beach closure. Red Tide Newslett. 1 (3): 7.

LAM, C.W.Y. and HO, K.C. 1989. Red Tides in Toto Harbour, Hong Kong. In: Red Tides: Biology, Environmental Science and Toxicology. (Okaichi, T., Anderson, D.M. and Nemoto, T., eds.) pp. 49-52. Elsevier Science Publishing Co., New York.

LANCELOT, C., BILlEN, G., SOURNIA, A., WEISSE, T., COLIJIN, F., VELHHIUS, M.J.W., DAVIES, A. and WASSMAN, P. 1987. Phaeocystis blooms and nutrient enrichment in the continental zones of the North Sea. Ambio. 16: 38-46.

LANDSBERG, J.H. 2002. The Effects of Harmful Algal Blooms on Aquatic Organisms.In: Reviews in Fisheries Science. 10 (2): 113-390.

LEE, J.S.; TORIGOE, K., ITO, A. and YASUMOTO, T. 1991. Variability in the occurrence of Dinophysis toxin -1 and Okadaic acid in various plankton species. Fifth International Conference on Toxic Marine Phytoplankton. Newport, Abstracts, p 73.

LENANTON, R.C.J., LONGERAN, N.R. and POTTER, I.C. 1985. Blue green algal blooms and the commercial fishery of a large Australian estuary. Mar. Poll. Bull. 16: 477-482.

LEWIS, R.J. and HOLMES, M.J. 1993. Origin and transfer of toxins involved in ciguatera. Biochem. Physiol. 106C: 615-628.

LEWIS, R.J., MOLGO, J. and ADAMS, D.J. 2000. Ciguatera toxins: pharmacology of toxins involved in ciguatera and related fish poisonings In: Seafood and Freshwater Toxins: Pharmacology, Physiology and Detection. (Botana, L.M., ed.) pp. 419-447. New York, Marcel Dekker.

LINDAHL, O. 1983. On the development of a Gyrodinium aureolum occurrences on the Swedish West Coast in 1982. Mar. Biol. 77: 143-150. 
LUNDHOLM, N., SKOV, J., POCKLINGTON, R. and MOESTRUP, Ø. 1994. Domoic acid, the toxin amino acid responsible for amnesic shellfish poisoning, now in Pseudonitzschia seriata (Bacillariophyceae), in Europe. Phycologia. 33: 475-478.

LUSH, G.J. and HALLEGRAEFF, G.M. 1996. High toxicity of the red tide dinoflagellate Alexandrium minutum to the brine shrimp Artemia salina In: Harmful and Toxic Algal Blooms. (Yasomoto, T, Oshima, Y. and Fukoyo, Y., eds.) pp. 609-610. Paris Intergovernmental Commission of UNESCO.

MACKENZIE, L. 1991. Toxic and noxious phytoplankton in Big Glory Bay, Stewart Island, New Zealand. J. Appl. Phycol. 3: 19-34.

MACLEAN, J.L. 1977. Observations on Pyrodinium bahamense Plate, a toxic dinoflagellate in Papua New Guinea. Limnol. Oceanogr. 22: 234-254.

MACLEAN, J. L. 1989. Indo-Pacific red tide occurrences, 1985-1988. Mar. Poll. Bull. 20: 304-310.

MAESTRINI, S.Y. and GRANELI, E. 1991. Environmental conditions and ecophysiological mechanisms which led to the 1988 Chrysochromulina polylepis bloom: an hypothesis. Oceanol. Acta. 14: 397-413.

MAHONEY, J. and STEIMLE, F.W. Jr. 1979. A mass mortality of marine animals associated with a bloom of Ceratium tripos in the New York Bight. In: Toxic Dinoflagellate Blooms. Proc. ${ }^{\text {nd }}$ Int. Conf. (Taylor, D.L. and Seliger, H.H., eds.) pp. 113-116. Elsevier.

MAHONEY, J.B., OLSEN, P. and COHN, M. 1990. Blooms of a dinoflagellate Gyrodinium cf. aureolom in New Jersy coastal waters and their occurrence and effects worldwide. J. Coast. Res. 6: $121-135$.

MARANDA, L., WANG, R., MASUDA, K. and SHIMIZU, Y. 1990. Investigation of the source of domoic acid in mussels. In: Toxic Marine Phytoplankton (Graneli, E., Sundstrom, B., Edler, L. and Anderson, D.M., eds.) pp. 300-304. Academic Press, New York.

MARTIN, J.L., HAYA, K., BURRIDGE, L.E. and WILDISH, D.J. 1990. Nitzschia pseudodelicatissima - a source of domoic acid in the Bay of Fundy; Eastern Canada. Mar. Ecol. Pro. Ser. 67: 177-182.

McMINN, A. 1989. Late Pleistocene dinoflagellate cysts from Botany Bay, New South Wales, Australia. Micrpaleontobiology. 35:1-9.

MELDAHL, A-S., EDVARDSEN, B. and FONNUM, F. 1994. Toxicity of four potentially ichthyotoxic marine phytoflagellates determined by four different test methods. J. Toxicol. Environ. Health. 42: 289-301.

MELDAHL, A.S., IVENSTUEN, J., GRASBAKKEN, G.J., EDVARDSEN, B. and FONNUM, F. 1995. Toxic activity of Prymnesium spp. and Chrysochromulina spp. tested by different test methods. In: Harmful Marine Algal Blooms. (Lassus, P., Arzul, G., Erard, E., Gentien, P. and Marcaillou Le-Baut, C. eds.) pp. 315-320. Lavoiser/ Intercept, Paris, France.

MOORE, R.E. 1977. Toxins from blue-green algae. Bioscience. 27: 797-802.

MOESTRUP, Ø. 1994. Economic aspects: "blooms", nuisance species, and toxins In: The Haptophyte Algae. (Green, J.C. and Leadbeater, B.S.C. eds.) Systematics Association Special Volume 51, pp. 265-285. Clarendon Press Oxford, New York.

MOSHIRI, G.A., CROMPTON, W.G. and BLAYLOCK, D.A. 1978. Algal metabolites and fishkills in a bayou estuary, an alternative explanation to the low dissolved oxygen controversy. J. Water Poll. Cont. Fed. 50: 2043-2046.

NAVINER, M.J., BERG, -P, DURAND, P. and Le BRIS, H. 1999. Antibacterial activity of the marine diatom Skeletonema costatum on against aquacultural pathogens. Aquaculture. 174: 1524.

NIELSEN, T.G., KIØRBOE, T. and BJORNSEN, P.K. 1990. Effects of a Chrysochromulina polylepis subsurface bloom on the plankton community. Mar. Ecol. Prog. Ser. 62: 21-35. 
NIJJAR, M.S. and NIJJAR, S.S. 2000. Ecobiology, clinical symptoms, and mode of action of domoic acid, an amnesic shellfish toxin. In: Seafood and Freshwater Toxins: Pharmacology, Physiology and Detection. (Botana, L.M., ed.) pp. 325-358. New York, Marcel Dekker.

NIXON, S.W. 1995. Coastal marine eutrophication: a definition, social causes and future concerns. Ophelia. 41: 199-200.

NOE-NYGAARD, F., SURLYK, K.F. and PIASECKI, S. 1987. Bivalve mass mortality caused by toxic dinoflagellate blooms in a Berrisian-Valanginian lagoon, Bornholm, Denmark. Palaio. 2: 263-273.

NOGA, E.J. 1998. Toxic algae, fish kills and fish diseases. Fish Pathol. 33 (4): 337-342.

NUZZI, R. and WATERS, R.M. 1989. The spatial and temporal distribution of "brown tide" in eastern Long Island. In: Novel Phytoplankton Blooms (Cosper, E.M., Bricelj, V.M. and Carpenter, E. J., eds.) pp.117-137. Springer, Berlin, Germany.

ODA, T., ISHIMATSU, A., TAKESHITA, S. and MURAMATSU, T. 1992. Hydrogen peroxide production by the red tide flagellate Chatonella marina. Biosci. Biotechnol. Biophys. 294: 3843.

OFFICER, C.B. and RYTHER, J.H. 1980. The possible importance of silicon in marine eutrophication. Mar. Ecol. Prog. Ser. 3: 83-91.

OKAICHI, T. 1989. Red tide problems in the Seto Inland Sea, Japan. In: Red Tides: Biology of Environmental Science and Toxicology. (Okaichi, T., Anderson, D.M. and Nemoto, T., eds.) pp.137-142. Elsevier Science Publishing Co., New York.

OKAICHI, T. and NISHIO, S. 1976. Identification of ammonia as the toxic principle of red tide of Noctiluca millaris. Bull. Plankton Soc. Jap. 23: 75-80.

OLSGARD, F. 1993. Do toxic algal blooms affect subtidal soft-bottom communities? Mar. Ecol. Prog. Ser.102: 269-286.

OLSSON, P., GRANELI. E. CARLSSON, P. and ABREU, P. 1992. Structuring of a post spring phytoplankton community by manipulation of trophic interactions. J. Exp. Mar. Biol. Ecol. Ser. 158: 249-266.

ONOUE, Y. 1990. Massive fish kills by a Ceratium fusus red tide in Kagoshima Bay, Japan. Red Tide Newsl. 3(2): 2.

OSTENFELD C.J. 1908. On the immigration of Biddulphia sinensis Grev. And its occurrence in the North sea during 1903-1907. Medelser fra Kommissionen for Havundersolgleser. Serie. Plankton. 1(6): 1-44.

PARKER, M. 1987. Exceptional plankton blooms conclusion of discussions: Conveners Report Rapp. P-V Reun. Cons. Int. Explor. Mer. 187: 108-114.

PARRISH, C.C., BODENNEC, G and GENTIEN, P. 1998. Haemolytic glycoglycerolipids from Gymnodium species. Phytochem. 47: 783-787.

PARTENSKY, F., LeBOTERF, J. and VERBUST, J.F. 1989. Does the fish killing dinoflagellate Gymnodium cf. nagasakiense produce cytotoxins? J. Mar. Biol. Assoc. UK. 69: 501-509.

PAULEY, K.E., SEGNEL, M.R., SMITH, J.C., MCLACHLAN, J.L. and WORMS, J. 1993. Occurrences of phycotoxins and related phytoplankton at winter temperatures in the southeastern Gulf of St. Lawrence, Canada. In: Toxic Phytoplankton Blooms in the Sea. (Smayda, T.J. and Shimizu, Y., eds.) vol. 3, pp. 311-316. Elsevier, Amsterdam.

PEPERZAK, L. 2003. Climate change and harmful algal blooms in the North Sea. Acta Oecologica. 24: S139-S144.

PERL, T.M., BEDARD, T. KOSATSKY, T., HOCKIN, J.C., TODD, E.C.D. and REMIS, R.S. 1990. An outbreak of toxic encephalopathy caused by eating mussels contaminated with domoic acid. New Eng. J. Med. 322: 1775-1780.

PEROVIC, S., TRETTER, L., BRUMMER, F., WETZLER, C., BRENNER, J., DONNER. G., SCHRODER, H.C. and MULLER, W.E. 2000. Dinoflagellates from marine algal blooms 
produce neurotoxic compounds: effects on free calcium levels in neuronal cells and synaptosomes. Environ. Toxicol. Pharmacol. 8: 83-94.

PIERCE, R.H. and KIRKPATRICK, G.J. 2001. Innovative techniques for harmful algal toxin analysis. Environ. Toxicol. Chem. 20: 107-114.

PLUMLEY, FG. 1997. Marine algal toxins: Biochemistry, genetics, and molecular biology. Limnol. Oceanogr. 42 (5 part 2): 1252-1264

POTTS, G.W. and EDWARDS, J.M. 1987. The impact of a Gyrodinium aureolum bloom on inshore young fish population. J. Mar. Biol. Assoc. UK. 67: 293-297.

PRICE, N.M., and MOREL, F.M. 1991. Co limitation of phytoplankton growth by nickel and nitrogen. Limnol. Oceanogr. 36: 1071-1077.

QI, S. and LI, D. 1994. Unequal cell division of Noctiluca scintillans. Oceanogr. Limnol. Sin. 25: 158-161.

QI, Y., LU, S. and ZHEN, L. 1995. An overview of harmful algal blooms (red tides) occurrence on coastal China and its research program in China. Proceedings of The International Conference on the Marine Biology of the South China Sea, Guangzhou, China. p.17-21.

QI, Y., ZHANG, Z. and HONG, Y. 1993. Occurrence of red tides on the coasts of China In: Toxic Phytoplankton bloom in the sea. (Smayda, T.J. and Shimizu, M., eds.) pp.43-46. Elsevier Science, PV.

QI, Y., HONG,Y. and QIAN, H.S. 1992. Problems caused by harmful algal blooms in China. Bmtc. Yolomar. 94: 22-24.

RAGELIS, E.P. 1984. Seafood toxins, ACS Symposium Series 262, pp.88 American Chemical Society, Washington, D.C.

RAUSCH de TRAUBENBERG, C. and MORLAIX, M. 1995. Evidence of okadaic acid into extracellular medium in cultures of Prorocentrum lima (Ehrenberg) Dodge. In: Harmful Marine Algal Blooms. (Larsus, P., Arzul, G., Erard-Le-Denn, E., Gentien, P. and Marcaillou-Le- Baut, C., eds.) pp. 493-498. Paris, Lavoiser.

RAVEN, J.A. and GEIDER, R.J. 1988. Temperature and algal growth. New Phycol. 110: 411-461.

REID, P.C., ROBINSON, G.A. and HUNT, H.G. 1987. Spatial and temporal patterns of marine blooms in the northeastern Atlantic and North Sea from the continuous plankton recorder survey. Rapp. P.V. Reun. Cons. Int. Explor. Mer. 187: 27-37.

RENSEL, J.E., HORNER, R.A. and POSTEL, J.R. 1989. Effects of phytoplankton blooms on salmon aquaculture in Puget Sound, Washington: initial research. Northwest. Environ. J. 5: 53-69.

RENSEL J.E. 1991. Severe blood hypoxia of Atlantic salmon (Salmo salar) exposed to marine diatom Chaetoceros concavicornis. Fifth International Conference on Toxic Marine Phytoplankton Newport. p106. (abstract).

RENSEL J.E. 1993. Severe blood hypoxia of Atlantic salmon (Salmo salar) exposed to the marine diatom Chaetoceros concavicornis In: Toxic Phytoplankton Blooms in the sea. (Smayda, T.J. and Shimizu, Y., eds.) Developments in Marine Biology , 3, pp. 625-630. Amsterdam, Elsevier, BV.

RHODES, L.L., HAYWOOD, A.J., BALLANTINE, W.J. and MACKENZIE, A.L. 1993. Algal blooms and climate anomalies in north-east New Zealand, August-December, 1992. N.Z. J. FW. Res. 27: 419-430.

RICHARDSON, K. 1989. Algal Blooms in the North sea. The good, the bad, and the ugly. Dana. 8: 89-93.

RICHARDSON, K. 1997. Harmful or exceptional phytoplankton blooms in the marine ecosystem. Adv. Mar. Biol. 31: 302-385.

RIEGMAN, R. and NOORDELOOS, A.A. 1991. Evidence for eutrophication induced Phaeocystis blooms in the Marsdiep area (The Netherlands). Fifth International Conference on toxic Marine phytoplankton, Newport. p.106 (abstract). 
RIGBY, G.R., STEVERSON, I.G. and HALLEGRAEFF, G.M. 1991. Environmental problems and the treatment options associated with international exchange of shipping ballast waters. Proceedings Chemeca Developing Export Conference, New Castle. 18-20 Sept. 1991. pp 221230.

RILEY, C.M., HOLT, S.A., HOLT, G.J., BUSKEY, E.J. and ARNOLD C.R. 1989. Mortality of larval red drum (Scianenops ocellatus) associated with a Ptychodiscus brevis red tide. Contrib. Mar. Sci. 31: 137-146.

ROBINEAU, B.J., GAGNE, A., FORTIER, L. and CEMBELLA, A.D. 1991. Potential impact of a toxic dinoflagellate (Alexandrium excavatum) bloom on survival of fish and crustacean larvae. Mar. Biol. 108: 293-301.

ROSENBERG, R., LINDALL, O. and BLANCK, H. 1988. Silent spring in the Sea. Ambio. 17: 289290.

RUTHERFORD, A. 2002. Fish nibbled not poisoned: Controversy over killer's algae's murderous methods://www.nature.com/nsu/020805. Nature News Service / Macmillan Magazines Ltd.

RYTHER, J.H. and DUNSTAN, W.M. 1971. Nitrogen, phosphorous and eutrophication in the coastal marine environment. Science. 171: 1008-1013.

SASNER, J.J., Jr., IKAWA, M. and FOXALL, T.L. 1984. Studies on Aphanizomenon and Microcystis toxins. In: Seafood toxins. (Ragelis, E.P., ed.) ACS Symposium Series 262, pp.391-406. American Chemical Society, Washington, D.C.

SAUNDERS, R.P. and GLENN, D.A. 1969. Diatoms Mem. "Hourglass” Cruises. Mar. Res. Lab. St. Petersburg, Florida.1 (3): 1-119.

SAVAGE, R.E. 1930. The influence of Phaeocystis on the migration of the herring. Min. Agric. Fish. Invest. Ser. 2. 12: 5-14.

SCHOLIN, C. 1998. Morphological, genetic, and biogeographic relationships of the toxigenic dinoflagellates Alexandrium tamarense. In: Physiological Ecology of Harmful Algal Blooms. (Anderson, D.M., Cembella, A.D. and Hallegraeff, G.M., eds.) pp.13-27. Heidelberg: SpringerVerlag.

SCHULMAN, L.S., ROSZELL, L.E., MENDE, T.J., WING, R.W. and BADEN, D.G. 1990. A new polyether toxin from Florida's red tide dinoflagellate. In: Toxic Marine Phytoplankton. (Graneli, E., Sundstrom, B., Edler, L. and Anderson, D.M., eds.) pp. 407-412. Academic Press, New York.

SEKI, T., SATAKE, M., MACKENZIE, L., KASPAR, H.F. and YASUMOTO, T. 1995. Gymnodine, a novel toxic imine isolated from the Foveaux strait oysters and the Gymnodium sp. Tetrahedron Lett. 7093-7096.

SELLNER, K.G., DOUCETTE, G.J. and KIRKPATRICK, G.J. 2003. Harmful algal blooms: causes, impacts and detection. Indian J. Microbiol. Biotechnol. 30 (7): 383-406.

SHILO, M. 1981. The toxic principles of Prymnesium parvum In: The Water Environment: Algal toxins and Health. (Carmichael, W.W. ed.) pp. 37-47. Plenum press, New York.

SHILO, M. and ASCHNER, M. 1953. The general properties of cultures containing the phytoflagellates Prymnesium parvum. Carter J. Gen. Microbiol. 8: 333-343.

SHIMIZU, Y., GUPTA, S., MASUDA, K., MARANDA, L., WALKER, C.K. and WANG, R. 1989. Dinoflagellate and other microalgal toxins: chemistry and biochemistry. Pure Appl. Chem. 61: 513-516.

SHIMIZU, Y. 1987. Dinoflagellate toxins. In: The Biology of Dinoflagellates. (Taylor, F.J.R., ed.) pp. 282-315. Blackwell, Oxford.

SHUMWAY, S.E. 1990. A review of the effects of algal blooms on shellfish and aquaculture. $J$. World Aqua. Soc. 21: 65-104.

SHUMWAY S.E. 1995. Phycotoxin related shellfish poisoning: bivalve mollusks are not the only vectors. Rev. Fish. Sci. 3:1-31. 
SKULBERG, O.M., CARMICHAEL, W.W., CODD, G.A. and SKULBERG, R. 1993. Taxonomy of toxic cyanophyceae (cyanobacteria). In: Algal Toxins in Seafood and Drinking Water. (Falconer, I.R., ed.) pp.145-164 Academic Press, London.

SMAYDA, T.J and VILLAREAL T. 1989. An extraordinary noxious brown tide in Narrangansett Bay. 1. The organism and its dynamic In: Red Tides, Biology, Environmental Science, and Toxicology. Proc. $1^{\text {st }}$ Int. Symp. on Red Tides. pp. 129-132. Elsevier.

SMAYDA, T.J. 1990. Novel and nuisance phytoplankton bloom in the sea: evidence for a global epidemic. In: Toxic Marine Phytoplankton. (Graneli, E., Sundstrom, B., Edler, L. and Anderson, D.M., eds.) pp. 29-40. Elsevier Science Publishing Co., New York.

SMAYDA T.J. 1992. Global epidemic of noxious phytoplankton blooms and food chain consequences in large ecosystems. In: Food chains, models and management of large ecosystems. (Sherman, K., Alexander, L.M. and Gold, B.D.eds.) pp. 275-307. Westview.

SMAYDA, T.J. 1997. Harmful phytoplankton blooms: their ecolophysiology and general relevance to phytoplankton blooms in the sea. Limnol Oceanogr. 42:1137-1153.

SOURNIA, A., CHRETIENNOT-DINET, M.J. and RICHARD, M. 1991. Marine phytoplankton: how many species in the world oceans? J. Plankton Res. 13(5): 1095-1099.

SOURNIA, A. 1995. Red Tide and toxic marine phytoplankton of the world ocean : an inquiry into biodiversity In: Harmful Marine Algal Blooms. (Lassus, P., Arzul, G., Erard-Le-Denn, E., Gentien, P. and Marcaillou-Le-Baut, C. eds.) pp. 103-112. Technique et Documentation, Lavoiser, Intercapt Ltd.

STEIDINGER, K.A. 1993. Some taxonomic and biologic aspects of toxic dinoflagellates. In: Algal Toxins in Seafood and Drinking Water. (Falconer, I.R., ed.) pp. 1-28. Academic.

STEIDINGER, K.A. 1996. Dinoflagellates In: Identifying Marine Diatoms and Dinoflagellates. (Thomas, C. ed.) pp. 387-598. San Diego, Academic Press.

STEIDINGER, K.A., BURKHOLDER, J.M., GLASGOW, H.B.Jr., TRUBY, E.W.; GARRET, J.K., NOGA, E.K. and SMITH, S.A. 1996. Pfiesteria piscicida, a new toxic dinoflagellate genus and species of the order Dinamoebales. J. Phycol. 32: 157-164.

STEIMLE, F.W and SINDERMANN, C.J. 1978. Review of oxygen depletion and associated mass mortality of shellfish in the Middle Atlantic Bight in 1976. Mar. Fish Rev. 40: 17-26.

SUBBA RAO, D.V., QUILLAM. M.A. and POCKLINGTON, R. 1998. Domoic acid - a neurotoxic amino acid produced by the marine diatom Nitzschia pungens in culture. Can. J. Fish. Aquat. Sci. 45: 2076-2079.

SUBBA RAO, D.V., PAN, Y. and SMITH, S.J. 1995. Allelopathy between Rhizosolenia alata (Brightwell) and the toxigenic Pseudonitzschia pungens f. multiseries. In: Harmful Marine Algal Blooms. (Lassus, P., Arzul, G., Erard-Le-Denn, E., Gentien, P. and Marcaillou-Le-Baut, C. eds.) pp. 329-334 Paris, Lavoiser.

SUGANUMA, M., FUJIKI, H. and SUGURI, H. 1988. Okadaic acid: an additional nonphorboltetradecanoate-13-acetate-type tumour promoter. Proc. Natl. Acad. Sci. U.S.A. 85: 17681771.

SWIFT, A.E.B. and SWIFT, T.R. 1993. Ciguatera. Clin. Toxicol. 31: 1-29.

TANGEN, K. 1977. Blooms of Gyrodinium aureolum (Dinophyceae) in north European waters, accompanied by mortality in marine organisms. Sarsia. 63: 123-133.

TANAKA, K., YOSHIMATSU, S. and SHIMADA, M. 1992. Generation of superoxide anions by Chatonella antiqua : Possible causes for fish death caused by "red tide". Experientia. 48: 888890.

TAYLOR, F.J.R. 1988. Plankton bloom occurrences in British Columbia (1987-1988). Red Tide Newslett. 1(2): 4-5. 
TAYLOR, F.J.R., TAYLOR, N.J. and WALSBY, J.R. 1985. A bloom of the planktonic diatom Ceratulena pelagica off the coast of North New Zealand in 1983, and its contribution to an associated mortality of fish and benthic fauna. Int. Rev. Gesamten. Hydrobiol. 70: 773-795.

TAYLOR, F.J.R., HAIGH, R. and SUTHERLAND, T.F. 1994. Phytoplnakton ecology of Sechelt Inlet, a fjord system on the British Columbia coast. 2. Potentially harmful species. Mar. Ecol. Prog. Ser. 103: 151-164.

TAYLOR, F.J.R., FUKUYO, Y. and LARSEN, J. 1995. Taxonomy of harmful dinoflagellates In: Manual on Harmful Marine Microalgae. (Hallegraeff, G.M., Anderson, D.M. and Cembella. A. eds.) pp.3539-3640. Paris, UNESCO.

TESTER, P.A.and MAHONEY, B. 1995. Implication of the diatoms Chaetoceros convolutus, in the death of red king crab Paralithoides camtschatica, Captains Bay, Unalaska, Alaska, In: Harmful marine algal blooms. Proc $6^{\text {th }}$ Intl Conf on Toxic Marine Phytoplankton. (Lassus, P., Arzul, G., Erard-Le-Denn, E., Gentien, P. and Marcaillou-Le-Baut, C., eds.) pp. 95-100. Lavoiser, Paris.

TETT, P. 1987. The ecophysiology of exceptional blooms. Rapp. Proc. Verb. Re'unions CIEM. 187: 47-60.

THRONDSEN, J. 1993. The planktonic marine flagellates In Marine Phytoplankton: a guide to naked eye flagellates and Cocclithophorids. (Thomas, C., ed.) pp. 7-146. San Diego, Academic Press.

TODD, E.C.D. 1990. Amnesic shellfish poisoning- a newseafood toxin syndrome. In:Toxic Marine Phytoplankton (Graneli, E., Sundstrom, B., Edler, L. and Anderson, D.M., eds.) pp. 504-508. Academic Press, New York.

TRACEY, J. 1988. Feeding reduction, reproductive failure and mortality in Mytilus edulis during the 1985 "brown tide” in Narangansett Bay, Rhode Island. Mar. Ecol. Prog. Ser. 50: 73-81.

TRAINER, V.L., EDWARDS, R.A., SZMANT, A.M., STUART, A.M., MENDE, T.J. and BADEN, T.G. 1990. Brevetoxins: unique activators of voltage-sensitive sodium channels. In: Marine Toxins, Origins, Structure and Molecular Pharmacology. (Hall, S. and Strichartz, G. eds.) vol. 418, pp. 168-175. Woods Hole, MA. U.S.A.

TURRIFF, N., RUNGE, J.A. and CEMBELLA, A.D. 1995. Toxin accumulation and feeding behavior of the planktonic copepod Calanus finmarchicus exposed to the red tide dinoflagellate Alexandrium excavatum. Mar. Biol. 123: 55-64.

VAN DOLAH , F.M. 2000. Marine algal toxins: Origins, effects and their increased occurrence. Health Perspect. 108: 133-141.

VOGEL, S. 1996. Life: in Moving Fluids. Princeton University Press, Princeton.

VOGELBEIN, W.K., LOVKO, V.J., SHIELDS, J.D., REECE, K.S., MASON, P., HASS, L.W. and WALKER, C.C. 2002. Pfiesteria shumwayae kills fish by micropredation not exotoxin secretion. Nature. 418 (6901): 67-69.

WAITE, A.M., THOMPSON, P.A. and HARRISON , P.J. 1992. Does energy control the sinking rates of marine diatoms? Limnol. Oceanogr. 37: 468-477.

WHITE, A.W. 1977. Dinoflagellate toxins as probable cause of an Atlantic herring (Clupea harengus harengus) kill, and pteropods as apparent vector. J. Fish Res. Board Can. 34: 2421-2424.

WHITE, A.W. 1979. Dinoflagellate toxins in phytoplankton and zooplankton fractions during a bloom of Gonyaulax excavata. In: Toxic Dinoflagellate Blooms. (Taylor, D.L. and Seliger, H.H. eds.) pp.381-384. New York: Elsevier.

WHITE, A.W. 1982. The scope of impact of toxic dinoflagellate blooms on finfish in Canada. Canadian Technical Report on Fish and Aquatic Sciences, 1063, Biological Station. Pp.5. St. Andrews, New Brunswick, Canada.

WHO. 1984. Aquatic (Marine and Freshwater ) Biotoxins. Environmental Health Criteria. 37. World Health Organisation, Geneva, Switzerland.

WIGLEY, T.M.L. and RAPER, S.C.B. 2001. Interpretation of high projections for global mean warming. Science. 293: 451-454. 
WORK, T.M., BAR, B., BEALE, A.M., FRITZ, L., QUILLIAM, M.A. andWRIGHT, J.L.C. 1992. Epidemiology of Domoic acid poisoning in brown pelican's and cormorants (Pelecanus occidentalis) and Brandt's cormorants (Phalacrocorax penicillatus) in California. J. Zool. Wildlife Med. 24: 54-62.

WORK, T.M., BEALE, A.M., FRITZ, L., QUILLIAM, M.A., SILVER, M., BUCK, K. and WRIGHT, J.L.C. 1993. Domoic acid intoxication of brown pelicans and cormorants in Santa Cruz, California. In: Toxic Phytoplankton Blooms in the Sea. (Smayda, T.J. and Shimizu, eds.) pp. 643-649. Amsterdam: Elsevier.

WRIGHT, J.L.C. and CEMBELLA, A.D. 1998. Ecophysiology and biosynthesis of polyether biotoxins In: Physiological Ecology of Harmful Algal Blooms. (Anderson, D.M, Cembella, A.D. and Hallegraeff, G.M., eds.) pp. 427-451.Heidelberg: Springer-Verlag.

WRIGHT, J.L.C., BOYD, R.K., de FREITAS, A.S.W., FALK, M., FOXALL, R.A., JAMIESON, D., LAYCOCK, M.V., McCULLOUGH, A.W., McINNES, A.G., ODENSE, P., PATHAK, V.P., QUILLIAM, M., RAGAN, A., SIM, P.G., THIEBAULT, P., WALTER, J.A., GILGAN, M., RICHARD, D.J.A. and DEWAR, D. 1989. Identification of domoic acid, a neuroexcitatory amino acid in toxic mussels from eastern Prince Edward Island. Can. J. Chem. 67: 481-490.

WYATT, T.1998. Harmful Algae, marine blooms and simple population models. Nature Resources. 34 (3): 40-51.

WYATT, T. and JENKINSON, I. 1997. Notes on Alexandrium population dynamics. J. Plankton Res. 19: $551-575$.

XIE, J., LI, J., LU, S., CHENG, O. and YANG, I. 1993. Features of red tide caused by Noctiluca scintillans off Yantian Coast with Dapeng Bay. Mar. Sci. Bull. 12: 1-16.

YANG, C.Z. and ALBRIGHT, L.J. 1992. Effects of harmful diatom Chaetoceros concavicornis on respiration of rainbow trout Oncorhynchus mykiss. Dis. Aquat. Org. 14: 105-114.

YANG, C.Z. and ALBRIGHT, L.J. 1994. The harmful phytoplankter Chaetoceros concavicornis causes high mortalities and leucopenia in Chinook salmon (Oncorhynchus tshawytscha) and coho salmon (Oncorhynchus kisutch). Can. J. Fish. Aquat. Sci. 51: 2493-2500.

YASUMOTO, T. 1985. Recent progress in the chemistry of dinoflagellate toxins. In: Toxic dinoflagellates. (Anderson, D.M., White, A.W. and Baden, D.J. eds.) pp. 259-270. Elsevier, New York.

YASUMOTO, T., OSHIMA, Y. and YAMAGUCHI, M. 1978.Ocurrence of a new type of shellfish poisoning in the Tokohu District. Bull. Jpn. Soc. Sci. Fish. 44: 1249-1255.

YASUMOTO, T., UNDERDAL, B., AUNE, T., HORMAZABAL, V., SKULLBERG, O.M. and OSHIMA, Y. 1990. Screening for hemolytic and ichthyotoxic components of Chrysochromulina polylepis and Gyrodinium aureolum from Norwegian waters, In: Toxic Marine Phytoplankton (Graneli, E., Sundstrom, B., Edler, L. and Anderson, D.M., eds.) pp. 436-440. Elsevier, New York.

YASUMOTO, T. and MURATA, M. 1993. Marine toxins. Chem. Rev. 93: 1897-1909.

Received 16 October 2004

Accepted 15 June 2005 